Review

\title{
New Therapeutic Approaches for Conjunctival Melanoma-What We Know So Far and Where Therapy Is Potentially Heading: Focus on Lymphatic Vessels and Dendritic Cells
}

\author{
Jennifer Peil ${ }^{1}$, Felix Bock ${ }^{1,2}$, Friedemann Kiefer ${ }^{3}$, Rebecca Schmidt ${ }^{4}$, Ludwig M. Heindl ${ }^{1}$, Claus Cursiefen ${ }^{1,2}$ \\ and Simona L. Schlereth $1,2, *$
}

check for

updates

Citation: Peil, J.; Bock, F.; Kiefer, F.; Schmidt, R.; Heindl, L.M.; Cursiefen, C.; Schlereth, S.L. New Therapeutic Approaches for Conjunctival Melanoma-What We Know So Far and Where Therapy Is Potentially Heading: Focus on Lymphatic Vessels and Dendritic Cells. Int. J Mol. Sci. 2022, 23, 1478. https:// doi.org/10.3390/ijms23031478 Academic Editor: Sharmila Masli

Received: 9 December 2021 Accepted: 24 January 2022 Published: 27 January 2022

Publisher's Note: MDPI stays neutral with regard to jurisdictional claims in published maps and institutional affiliations.

Copyright: (c) 2022 by the authors Licensee MDPI, Basel, Switzerland. This article is an open access article distributed under the terms and conditions of the Creative Commons Attribution (CC BY) license (https:// creativecommons.org/licenses/by/ $4.0 /)$
1 Department of Ophthalmology, Faculty of Medicine and University Hospital Cologne, University of Cologne, 50937 Cologne, Germany; jennifer.peil@uk-koeln.de (J.P.); felix.bock@uk-koeln.de (F.B.); ludwig.heindl@uk-koeln.de (L.M.H.); claus.cursiefen@uk-koeln.de (C.C.)

2 Center for Molecular Medicine Cologne (CMMC), University of Cologne, 50937 Cologne, Germany

3 European Institute for Molecular Imaging (EIMI), University of Münster, 48149 Münster, Germany; fkiefer@gwdg.de

4 Department of Oral, Maxillofacial and Plastic Facial Surgery, Medical Faculty and University Hospital Düsseldorf, Heinrich Heine University, 40225 Düsseldorf, Germany; Buschr@hhu.de

* Correspondence: Simona.schlereth@uk-koeln.de

\begin{abstract}
Conjunctival melanoma (CM) accounts for 5\% of all ocular melanomas and arises from malignantly transformed melanocytes in the conjunctival epithelium. Current therapies using surgical excision in combination with chemo- or cryotherapy still have high rates for recurrences and metastatic disease. Lately, novel signal transduction-targeted and immune checkpoint inhibitors like cytotoxic T-lymphocyte-associated protein 4 (CTLA-4) inhibitors, programmed cell death protein1 (PD-1) receptor inhibitors, BRAF- or MEK-inhibitors for systemic treatment of melanoma have improved the outcome even for unresectable cutaneous melanoma, improving patient survival dramatically. The use of these therapies is now also recommended for CM; however, the immunological background of CM is barely known, underlining the need for research to better understand the immunological basics when treating $\mathrm{CM}$ patients with immunomodulatory therapies. Immune checkpoint inhibitors activate tumor defense by interrupting inhibitory interactions between tumor cells and T lymphocytes at the so-called checkpoints. The tumor cells exploit these inhibitory targets on T-cells that are usually used by dendritic cells (DCs). DCs are antigen-presenting cells at the forefront of immune response induction. They contribute to immune tolerance and immune defense but in the case of tumor development, immune tolerance is often prevalent. Enhancing the immune response via DCs, interfering with the lymphatic pathways during immune cell migration and tumor development and specifically targeting tumor cells is a major therapeutic opportunity for many tumor entities including CM. This review summarizes the current knowledge on the function of lymphatic vessels in tumor growth and immune cell transport and continues to compare DC subsets in CM with related melanomas, such as cutaneous melanoma and mucosal melanoma.
\end{abstract}

Keywords: dendritic cells; conjunctival melanoma; cDC1; cDC2; pDCs; lymphatic; immunotherapy

\section{Introduction}

Melanomas vary in their behavior, genetics, and response to therapies. It is, therefore, important to look at melanoma subtypes in a differentiated way. Currently, we are seeing significant therapeutic success for cutaneous melanoma with molecular inhibitors and immune checkpoint inhibitors. Success in ocular melanoma is limited because of the lack of therapeutic standards and clinical trials for conjunctival melanoma (CM) and, in general, too little is known about the immunology of ocular tumors and the tumor microenvironment. 
We, therefore, may miss ocular features if drugs tested only for cutaneous melanomas are uncritically applied to ocular melanoma patients. It is important not to consider or treat all melanomas the same. For example, another completely different ocular melanoma subtype is uveal melanoma. It originates from non-epithelial melanocytes and differs significantly compared to dermal, mucosal and conjunctival melanoma in terms of mutations, with mostly primary mutations located in GNAQ or GNA11, [1,2], which are not of importance in cutaneous melanoma or CM. Uveal melanoma metastasizes, primarily hematogenous, into the liver, different from CM and cutaneous melanoma and does respond less to immune checkpoint inhibitors (20-30\%) [3], compared to metastatic cutaneous melanoma (40-60\%) [4].

The overall mortality rate, e.g., for CM, is still high and is approximately 30\% [5]. Therefore, the improvement of systemic or local therapies, especially for metastatic cases, is crucial. There are some particularities especially in the eye compared to the skin. Here, resection of larger tumors or the adherence to all resection margins may be associated with functional losses.

This review summarizes the similarities and differences of CM (summarized in Table 1) compared with its closest relatives, cutaneous melanoma and mucosal melanoma, and highlights new therapeutic approaches for the future for all three forms of melanoma. We address the epidemiology, clinic and etiology, and genetics of CM, cutaneous melanoma, and mucosal melanoma. Current and new therapeutic approaches will be discussed. The focus of potential new therapeutic approaches includes mainly dendritic cells (DCs) and lymphangiogenesis.

Table 1. Similarities and differences between conjunctival, cutaneous and other mucosal melanomas.

Similarities of Cutaneous, Mucosal and Conjunctival Melanoma:
Differences Between Cutaneous, Mucosal and Conjunctival Melanoma:

CM has an average thickness of only $33 \mu \mathrm{m}$ [10] compared to the dermal epithelium thickness of an average of $2 \mathrm{~mm}$ and mucosal thickness, e.g., oral mucosa $0.1-0.5 \mathrm{~mm}$.

All arise from melanocytes [6].

Conjunctiva and mucosa contain several mucosa and skin originate from the surface ectoderm [7].

Origin, embryology and All three contain anatomical particularities different from the skin [11], e.g., goblet cells, which produce mucin [12], B-cells: the so called conjunctiva-associated lymphoid tissue (CALT) [8], the mucosal associated lymphoid tissue (MALT) or the skin-associated lymphoid tissue (SALT) [9]. express transforming growth factor $\beta 2$ (TGF- $\beta 2$ ) and are able to induce tolerogenic DCs $[13,14]$. Loss of goblet cells correlates with more severe conjunctival diseases, like dry eye syndrome [15]. The skin is keratinized, whereas conjunctiva and mucosa are non-keratinized.

Highest incidence (per year) in cutaneous melanoma $(19.7 / 100,000)[16]$, compared to $0.2-0.8 / 1,000,000)$ in CM [17], and

Incidence $1.5-2.8 / 1,000,000$ cases in mucosal melanoma [18].

$\mathrm{UV}$ radiation is a clear risk factor in cutaneous

Risk factors melanoma, whereas in CM the role of UV radiation is not completely understood [19] and in mucosal melanoma UV radiation is not of importance.

\begin{tabular}{|c|c|c|c|}
\hline Mutations & - & $\begin{array}{l}\text { Cutaneous melanoma and CM show similarly high } \\
\text { mutation rates in the BRAF, NRAS, TERT and KIT } \\
\text { genes [20]. }\end{array}$ & $\begin{array}{l}\text { - TERT mutations are very rare in mucosal } \\
\text { melanoma, whereas KIT mutations are the most } \\
\text { frequently altered oncogene in mucosal } \\
\text { melanomas [21] (different from cutaneous or CM). }\end{array}$ \\
\hline Metastasis & - & $\begin{array}{l}\text { All metastasize via lymphatic and hematogenous } \\
\text { spread [17]. }\end{array}$ & \\
\hline
\end{tabular}

\section{Conjunctival Melanoma}

\subsection{Epidemiology}

Five percent of all ocular melanomas are CMs [5]. The incidence in the Caucasian population is $0.2-0.8$ cases per million and year, with men and women being equally affected [22-26]. In relation to the surface area, the incidence of CM is equal to cutaneous 
melanoma [27]. The mean age of diagnosis is between $55-65$ years $[5,17,18]$. Less than $1 \%$ of $\mathrm{CM}$ cases occur within the black population and the tumor is also very rare in Asians [22,28], but with an increasing incidence [29,30]. An increase in incidence is also seen in cutaneous melanoma, but not in uveal melanoma [31].

\subsection{Clinic, Etiology and Risk Factors}

$\mathrm{CM}$ is an asymptomatic pigmented plaque, macule, or tumor often surrounded by feeder blood vessels $[17,24,32]$. CM appears on bulbar conjunctiva in $92 \%$ of cases, the temporal quadrant (63\%), touches the limbus (61\%) and can also appear in the palpebral and forniceal conjunctiva, plica semilunaris and caruncula [32] (Figure 1). CM arises from malignantly transformed melanocytes in the basal layer of the epithelium [5,33]. The risk factors of CM are not completely understood. For cutaneous melanoma, it is known that risk factors are, for example, family history, UV light exposure and genetic syndromes like xeroderma pigmentosum, Hodgkin lymphoma and familial melanoma syndromes [34-38]. In CM there are published case reports of patients with Xeroderma pigmentosum and CM [37,39]. The conjunctiva is the only mucous membrane exposed to UV radiation. This sunlight exposition is thought to be involved in the development of sun-exposed CM [40-42].

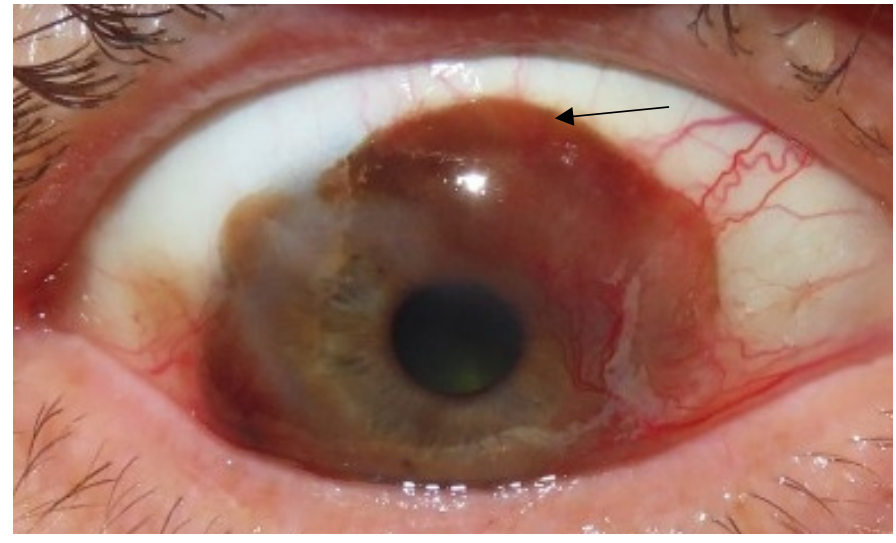

(a)

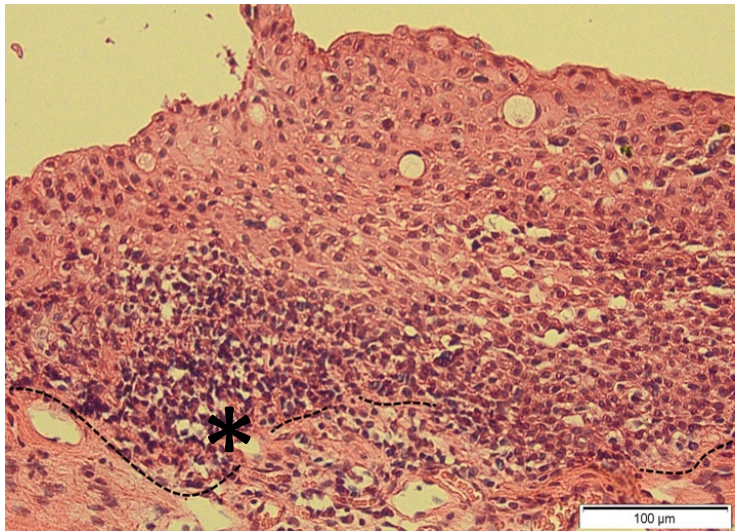

(b)

Figure 1. (a) Clinical picture of CM shows the pigmented tumor overgrowing the limbus and prominent feeder vessels (arrow); (b) Histological picture (Hematoxylin Eosin) of CM: The architecture of the epithelium is destroyed and the basal membrane (broken line) is disrupted by the tumor. Asterisk $\left.{ }^{*}\right)$ marks an accumulation of atypical melanocytes characterized by pyknic and basophil cell bodies.

Several studies indicate that mucosal melanoma is not associated with human papilloma viruses, human herpes viruses and polyomaviruses [43-46]. It has been suggested that smoking is a risk factor for oral mucosal melanoma because oral pigmented lesions are more frequent among smokers [47]. Exposure to formaldehyde was suggested as risk factor for sinonasal mucosal melanoma [48,49]. Patients with HIV have a higher risk to develop anorectal mucosal melanoma [43]. Risk factors for vulvovaginal mucosal melanoma are potentially chronic inflammatory conditions, viral infections and chemical irritants [43]. $\mathrm{CM}$ is associated with conjunctival intraepithelial, melanocytic neoplasia (C-MIN, formally called primary acquired melanosis (PAM)) and nevi $[5,50]$. Especially in C-MIN with atypia, there is a high CM risk (53\% to 75\% of all cases) [17]. CM can further develop from a conjunctival nevus, which occurs in 5\% of the cases, or can be formed de novo without any preceding lesion, which occurs in $18 \%$ to $30 \%$ of the cases [51-53].

\subsection{Genetic Background}

In $\mathrm{CM}$, mutations in the mitogen-activated protein kinase $(M A P K)$ and Phosphoinositide 3-kinases (PI3K)/protein kinase B (AKT)/mechanistic target of rapamycin (mTOR) 
pathway have been shown [54-56]. Mutations in the proto-oncogenes NRAS, BRAF, KIT, or the tumor suppressor gene neurofibromin 1 (NF1) lead to an increase in signal transduction from the cell membrane to the nucleus, which in turn activates differentiation, growth and survival [57-59]. Mutations in NRAS, a small GTPase, are found in approximately $20 \%$ of CM and in up to $30 \%$ of cutaneous and other mucosal melanomas [20,40,57,58,60-62]. NRAS activates $B R A F$ a component of the MAPK pathway and PI3-K of the PI3-K/AKT/mTOR pathway $[63,64]$. Mutations in $B R A F$ occur in $14-50 \%$ of $C M$ cases. The most frequent $B R A F$ mutation is the V600E mutation (80-90\%), [62,65-67]. BRAF activates the mitogenactivated protein kinase (MEK) protein by phosphorylation, which leads to activation of the extracellular-signal regulated kinases (ERK) protein, leading to cell growth [59].

$B R A F^{\mathrm{V} 600 \mathrm{E}}$ mutations are typically found in cutaneous melanoma areas without sun damage and develop from nevi [68,69], while atypical mutations in BRAF are found in sun exposed skin melanoma [70]. Compared to the number of BRAF mutations in cutaneous melanoma (32-60\%) $[20,56,71-74]$, it is relatively rare in other mucosal melanomas (3-10\%) [20,75-79]. In CM, BRAF mutations are found in the sun-exposed epibulbar conjunctiva with a more than twofold frequency [68].

An NF1 dysfunction occurs in 30\% of CM, in $8-18 \%$ in mucosal melanoma and in $12-25 \%$ in cutaneous melanoma $[20,80]$. NF1 is, as mentioned above, a tumor suppressor protein [81].

Mutations in the promoter of the telomerase reverse transcriptase (TERT) are found in $32-43 \%$ of CM [41,82]. TERT mutations are mainly found in UV exposed areas and correlate with a shorter metastatic free survival [82]. They are not detectable in conjunctival nevi or PAM without atypia [83]. TERT mutations have been seen in $85 \%$ of metastatic cutaneous melanoma tissues, and 33\% of primary cutaneous melanomas [84], but are very rare in mucosal melanoma $(8 \%)$ [85].

Mutations in the receptor tyrosine kinase KIT (CD117), a member of the PI3K/AKT/mTOR pathway, have been detected in $0-11 \%$ of $\mathrm{CM}$ cases $[17,20,86]$. KIT mutations are very rare in cutaneous melanoma (0-2\%) and occur more often in mucosal melanoma (4-21\% of cases) [20,21]. The mutational activation of KIT leads to ligand-independent autophosphorylation of intracellular tyrosine residues, resulting in downstream activation of PI3K [87]. KIT is crucial for the normal development of melanocytes acting as an important mitogen [88].

\subsection{Prognosis}

The total mortality of CM is around 30\% [5]. The tumor can metastasize via lymphatic and hematogenous pathways and rapidly colonizes draining regional lymph nodes [17,52,89]. Distant metastases are seen in the liver, brain, skin, gastrointestinal tract and lungs [90,91]. The survival rate of CM is 74-86\% after five years and $41-78 \%$ after 10 years [30,51,92-94]. The local recurrence rate of $36-62 \%$ is high $[17,95]$. This poor prognosis may improve in the future, due to novel immune checkpoint therapies, but except for case reports, prognostic data for larger cohorts are presently not available.

\subsection{Treatment Strategies}

The preferred therapy for local CM is surgical excision combined with brachy-, cryo-, chemo- or immunotherapy [24,95] (reviewed in detail by Brouwer et al. [27]). Because of the high recurrence rate of up to 66\% [51] after surgical excision in combination with adjuvant therapy, there is a need for new and more successful treatment options. For metastatic disease, there is currently no standardized therapy for CM [20]. Due to missing standards, therapy is often adjusted to cutaneous melanoma. The European guideline for melanoma does not even mention CM separately [96], which does not simplify the treatment of affected patients. Depending on their localization, singular metastases can be surgically removed or irradiated. Until a few years ago, there were no curative therapies for broadly metastasized stages of CM. This situation has improved with the introduction 
of molecular inhibitors or immunomodulatory therapies. However, only case reports or in vitro studies have been published (compare Table 2).

A wide range of new therapeutic approaches have already made it into clinical trials. Already today, patients with dermal melanoma from AJCC 2017 stage IIIA-D are offered an anti-PD1 therapy, or from stage III A-D with a BRAF V600E or V600K mutation are offered a BRAF and MEK inhibitor, as this prolongs the recurrence-free survival, according to the melanoma guideline [97-99]. Similar is the approach in patients with CM with or without $B R A F$ mutations or advanced disease, although there are no studies on this. Novel treatment options are summarized in Table 2.

Table 2. Summary of available molecular inhibitors, immune checkpoint inhibitors and DC vaccination therapeutics, that have been tested in cutaneous and/or CM.

\begin{tabular}{|c|c|c|c|c|}
\hline \multirow{17}{*}{ Molecular inhibitors } & \multirow{2}{*}{ Target } & \multirow{2}{*}{$\begin{array}{l}\text { Commercial } \\
\text { Name }\end{array}$} & \multicolumn{2}{|c|}{ Tested in } \\
\hline & & & Cutaneous Melanoma & Conjunctival Melanoma \\
\hline & \multirow{3}{*}{ BRAF } & Vemurafenib & yes $[64,100-102]$ & $\begin{array}{c}\text { yes (5 patients }++3 \text { human CM } \\
\text { cell lines) [102-107] }\end{array}$ \\
\hline & & Dabrafenib & yes [108,109] & yes (2 patients + ) $[40,110,111]$ \\
\hline & & Encorafenib & yes [112] & no \\
\hline & \multirow{4}{*}{ MEK } & Cobimetinib & yes $[64,100]$ & yes (1 patient + ) [106] \\
\hline & & Trametinib & yes $[108,109]$ & $\begin{array}{l}\text { yes (1 patient }++3 \text { human CM } \\
\text { cell lines) }[102,110]\end{array}$ \\
\hline & & Binimetinib & yes [112] & $\begin{array}{c}\text { yes (only in } 3 \text { human CM cell } \\
\text { lines) [113] }\end{array}$ \\
\hline & & Selumetinib & yes [114] & $\begin{array}{c}\text { yes (only in } 3 \text { human CM cell } \\
\text { lines) [102] }\end{array}$ \\
\hline & \multirow{2}{*}{ PI3K } & Dactolisib & yes [115] & $\begin{array}{c}\text { yes (only in } 3 \text { human CM cell } \\
\text { lines) [102] }\end{array}$ \\
\hline & & Pictilisib & yes [116] & $\begin{array}{c}\text { yes (only in } 3 \text { human CM cell } \\
\text { lines) [102] }\end{array}$ \\
\hline & mTOR & Dactolisib & yes [115] & $\begin{array}{c}\text { yes (only in } 3 \text { human CM cell } \\
\text { lines) [102] }\end{array}$ \\
\hline & AKT & MK-2206 & yes [117] & $\begin{array}{l}\text { yes (only in } 3 \text { human CM cell } \\
\text { lines) [63] }\end{array}$ \\
\hline & MEK & Binimetinib & yes [112] & $\begin{array}{l}\text { yes (only in } 3 \text { human CM cell } \\
\text { lines) [63] }\end{array}$ \\
\hline & KIT & Imatinib & yes [118-120] & no \\
\hline & $\mathrm{CDK} 4 / 6$ & Ribociclib & yes [121] & no \\
\hline & ERK1/2 & Ulixertinib & yes [122] & no \\
\hline \multirow{3}{*}{$\begin{array}{l}\text { Immune checkpoint } \\
\text { inhibitors }\end{array}$} & CTLA-4 & Ipilimumab & yes [123-125] & yes (7 patients $\ddagger)$ [126-128] \\
\hline & \multirow{2}{*}{ PD-1 } & Nivolumab & yes $[125,129]$ & yes (4 patients $\ddagger)[126,128]$ \\
\hline & & Pembrolizumab & yes [130] & $\begin{array}{l}\text { yes }(7 \text { patients } \ddagger) \\
{[103,126,128,131]}\end{array}$ \\
\hline DC vaccination & & Sipuleucel-T & Clinical trial still ongoing & \\
\hline
\end{tabular}

\subsubsection{Molecular Inhibitors}

One possibility for new therapy is the treatment with targeted molecular inhibitors. The MAPK and PI3K/AKT/mTOR pathways provide molecular targets $[59,65]$. Both 
pathways are highly activated due to mutations in the BRAF, NRAS, NF1, and KIT genes as mentioned above. In case reports, BRAF inhibitors in combination with or without MEK inhibitors have shown good therapeutic effects, up to complete response, with acceptable side effects $[103,106]$.

Cao et al. showed that inhibition of both BRAF and MEK act synergistically, at least in three CM cell lines (CRMM1, CM2005 and CRMM2) and was more effective than BRAF inhibition alone [63]. Similar results have been observed in cutaneous melanoma with $B R A F$ and NRAS mutants, reviewed in [132].

Unfortunately, studies using KIT inhibition with imatinib do not exist in CM [20], probably because KIT mutations were rarely detected in CM (see Section 2.3). However, patients with metastatic mucosal melanoma benefit from therapy with imatinib [118,119].

\subsubsection{Immune Checkpoint Inhibitors}

Further therapeutic options comprise immune checkpoint inhibitors. These therapeutic approaches have recently been applied to advanced or metastatic stages but also in patients with CM lacking BRAF- or KIT mutants.

Immune checkpoint inhibitors interfere with T-cell function: As mentioned above, DCs are crucial in initiating strong immune responses or inducing tolerance, with both ways being strictly regulated: Induction of tolerance is under the control of immune checkpoint pathways, like cytotoxic T-lymphocyte-associated protein 4 (CTLA-4) or programmed cell death protein-1 (PD-1) [133] and immune stimulation by signals like pathogen-associated molecular patterns (PAMPs) [134]. Therefore, when DCs express CTLA-4 or PD-1, T-cells are inhibited or differentiate into regulatory T-cells [133]. Tumor cells exploit this mechanism by also expressing PD-1 or CTLA-4 to generate an immune-tolerant environment. Immune checkpoint inhibitors (for example ipilimumab, nivolumab and pembrolizumab) are monoclonal antibodies, which target the ligands of these inhibitory T-cell receptors [135]. When the CTLA-4 ligands CD80 and CD86 or the PD-1 ligand PDL- 1 are expressed by tumor cells, they effectively inhibit activation of cytotoxic T-cells and foster escape from recognition and elimination by the immune system [65,136-139]. Immune checkpoint inhibitors stop this inhibitory effect by binding to the regulatory receptors on T-cells, which leads to activation of the immune system against tumor cells [140]. PD-1 is further expressed on natural killer cells, B-cells and monocytes [112,141-143]. In CM, PD-1 inhibitor nivolumab induced a complete response to metastatic disease in four patients up to 36 months of follow up [126]. Another PD-1 inhibitor, pembrolizumab, showed responses with mixed results in other case reports [103,126,128].

The CTLA-4 inhibitor ipilimumab is an approved therapy option for metastatic cutaneous melanoma [20]. In a case report using ipilimumab, there was no recurrence of primary or metastatic CM at 16 months of follow-up [127].

Furthermore, in case of insufficient response different immune checkpoint inhibitors can be combined (like a PD-1 inhibitor together with a CTLA-4 inhibitor), however, at the cost of increased side effects including diarrhea, fatigue, pruritus or nausea [128,144-147]. Ocular side effects are rare (1.3\%) [148] and include dry eyes, panuveitis or orbital inflammation $[149,150]$.

Initial clinical studies showed positive effects of therapeutic inhibition of ERK1/2, the PI3K-AKT-mTOR pathway and CDK4/6 in cutaneous melanoma [20]. In the long term, these may also be valid options for the treatment of metastatic CM patients.

Although initial studies have yielded promising results, only case reports of immune checkpoint inhibitors in CM are currently available and no larger, controlled trials have yet been conducted.

\subsubsection{Vaccination}

DC vaccination is another hot topic in oncology and several studies have been performed to understand the mechanisms behind this approach and clinical trials were performed or are ongoing, summarized in [151], although not in CM yet. 
DCs are able to initiate adaptive immune responses [152] and activate memory and naïve B- and T- cells as well as cells of the innate immunity including natural killercells [153]. To not solely rely on endogenous and in the tumor context often immuneincompetent DCs, there is a need of applying functional DCs as part of antigen-based cancer vaccines [154].

DC vaccination entails the adoptive transfer of autologous, activated, or antigenloaded DCs into cancer patients. The DCs are isolated or generated in vitro and manipulated before reinfusion [151]. This has already been performed in clinical trials for melanoma and other cancer types [155,156]; however, for melanoma, a clinically approved DC vaccination does not exist so far. Still, the studies showed that DC vaccination is safe and induces antitumor responses [151]. Indeed, for prostate cancer a DC vaccination made it to clinical implementation: Sipuleucel-T (Provenge) is the first FDA approved therapeutic cancer vaccine for metastatic prostate cancer and it prolongs the median survival by 4.1 months [157].

The overall patient response rate using DC vaccination is up to $15 \%$ [158,159], which is a significant success because very often these patients suffer from end-stage cancers. López et al. showed increased survival of patients with melanoma after vaccination with DCs loaded with melanoma cell lysates [160]. In this study, 43 stage IV and seven stages III patients were vaccinated with DCs four times [160]. The stage IV patients had an overall survival of 15 months and the stage III patients had a median tumor free period of 48-month follow-up [160].

\section{The Lymphatic Vasculature in Immune Cell Migration and Tumor Development}

Lymphatic vessels play a central role in the maintenance of tissue fluid balance, dietary lipid absorption and the trafficking of immune cells [161]. In healthy tissue, blind ending initial or capillary vessels of the mature lymph vessel system take up interstitial fluids, solutes and extravasated immune cells and transport this complex mixture "the lymph" via collecting vessels to the draining lymph nodes [162,163]. For efficient uptake, capillary lymphatic endothelial cells (capLECs) are endowed with specialized button junctions where focal accumulations of endothelial adhesion and tight junction molecules alternate with long intermittent membrane stretches rich in PECAM-1 and the hyaluronan receptor LYVE-1 [161,164], leading to a characteristic oak leaf shape (Figure 2).

From capillaries, the lymph is channeled via pre-collectors into collecting lymphatic vessels, which carry it to the regional lymph nodes and after exiting through efferent lymphatics via the left and right lymphatic duct to the venous circulation.

Elegant cannulation studies, which analyzed the composition of lymph by tracing immune cells, labeled with photo-convertible fluorescent proteins, identified T-cells as major cargo of afferent lymphatics followed by antigen presenting DCs and few B-cells [165,166]. Performing continuous immune surveillance for cognate antigen, these populations enter afferent lymphatics and rapidly stimulate recall immune responses in the draining regional lymph nodes. Interestingly, the overwhelming majority of recirculating T-cells in the lymph are $\mathrm{CD} 4+$, of which $25 \%$ are comprised of FOXP3+ regulatory T-cells. The high percentage of Tregs in lymph provides solid evidence for the role of lymphatic vessels in immunoregulatory functions [166]. In the steady state, few DCs that populate the lymph clearly also contribute to the maintenance of peripheral and oral tolerance $[167,168]$. DC numbers massively rise during inflammation, when DCs present immune stimulatory antigens in the regional nodes [169]. In all these scenarios, the major chemokine produced by lymphatic capillaries is CCL21, guiding vessel entry of CCR7+ T-cells and DCs [170-173]. 

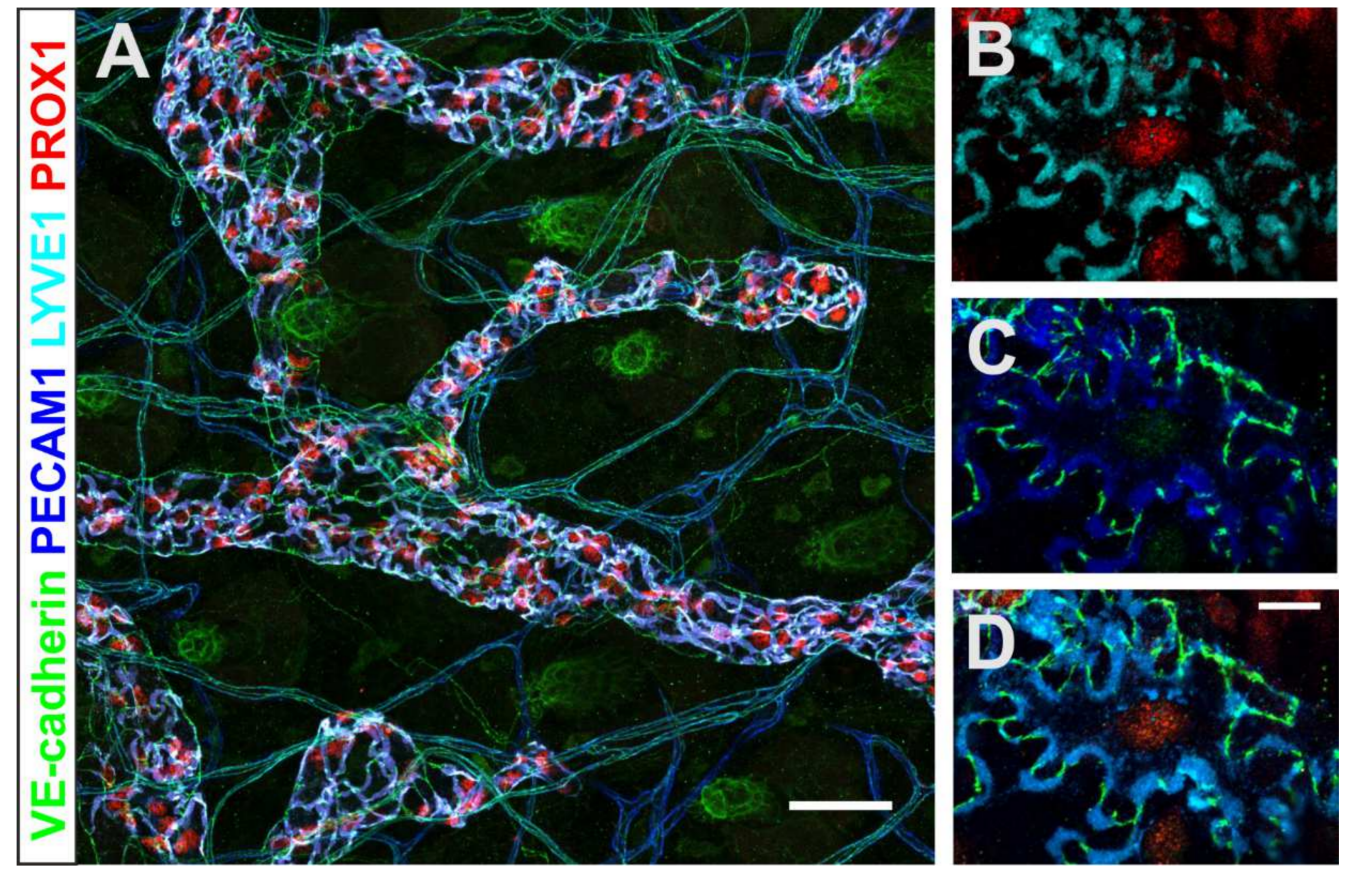

Figure 2. Lymphatic capillaries in mouse dermis. Such high-resolution images of the conjunctiva are not yet available. (A) Maximum intensity projection of wholemount stained mouse dermal lymphatic capillaries. The combination of endothelial-specific (VE-cadherin, PECAM-1) lymph vessel specific (PROX1) and capillary (LYVE1) markers unambiguously identifies lymphatic capillaries. (B-D) Higher magnification depicts the prototypic oak-leaf shape of capillary LECs and the button junctions formed by VE-cadherin, which alternates with LYVE1 and PECAM-1. The colors of the depicted epitopes are indicated on the left. Scale bars (A) $50 \mu \mathrm{m}$, (D) $10 \mu \mathrm{m}$.

Developmentally, already the earliest lymphatic progenitors express the transcription factor PROX1 and appear at the dorsal roof of the cardinal vein [174]. PROX1 is essential for the differentiation and maintenance of LECs. Through further migration and sprouting, LECs form a primitive lymphatic plexus, in a process that is regulated and dependent on the vascular endothelial growth factor receptor-3 (VEGFR3). Two cognate growth factors VEGF-C and -D trigger VEGFR3 signaling-mediated responses in LECs, but developmental regulation overwhelmingly depends on VEGF-C [163,175].

Following postnatal maturation, the lymphatic vessel system acquires a quiescent state. LEC quiescence may also be revoked by lymphangiogenic, physiologic, but mainly pathologic stimuli, including tumor development, but also wound healing, obesity, or inflammatory scenarios like myocardial infarction, inflammatory bowel disease, or corneal transplantation [176-178]. In inflammatory scenarios, the action of lymphatic vessels is Janus-faced. While they provide easy access for pro-inflammatory antigen presenting cells to the regional lymph nodes, at the same time they contribute to antigen clearance and facilitate the trafficking of immunomodulatory cells, including the aforementioned Tregs, and thereby can contribute to the efficient resolution of inflammation. Many tumor cells, but also tumor-associated inflammatory cells are rich sources of VEGF-C and VEGF-D, causing the development of extensive peri-tumoral but also tumor-invading lymph vessels that may serve as conduits for metastasis dissemination $[179,180]$. CD146, a cell adhesion molecule, is involved in driving melanoma progression and metastasis, particularly in vascular and lymphatic metastasis via VEGF-R2 [181]. Tumor associated lymphangiogenesis is generally associated with poor prognosis $[182,183]$, however, at the same time tumor lymph vessels may provide benefits for the generation of an anti-tumor immune response during checkpoint inhibition immune therapy [184-186].

The conjunctiva contains lymphatic vessels, which lately have been shown ex vivo using OCT signaling in porcine eyes [187] or in vivo in mice and rats [188]. In human fetal 
samples, the conjunctiva shows lymphatic vessels as early as week 17 of gestation [189]. Even in adults, the lymphatic status of ocular tissues is actively regulated by pro- and angiogenic factors [190].

Regarding CM, the presence of lymphatic vessels has been demonstrated in a CM mouse model [191], as well as in human CM samples [192,193]. In patients, lymphangiogenesis was associated with an increased risk of recurrence, metastasis and tumor-related death [194]. Tumor samples expressed VECF-C, -D and -R3, as well as CXCL12, CCL21 and CXCR4 with the highest lymphatic vessel density at the invasive tumor edges [195]. In CM, the lymphangiogenic stimulus is triggered very early, even before the invasive phenotype of the tumor appears [192,194].

The interaction of DCs and tumor draining lymphatic vessels but also tumor-induced changes in lymph nodes have been studied poorly in CM. Tumor draining lymph nodes often present an altered immunologic microenvironment compared to non-tumor-associated lymph nodes. An increased frequency of regulatory T-cells in tumor-draining lymph nodes correlates with a worse prognosis for cutaneous melanoma patients. [196]. This is another potential therapeutic option to not only strengthen DCs locally in their antitumor response but also to promote their pathway to the lymph nodes, where the immune system is activated against the tumor.

\section{Dendritic Cell Function in General, in the Conjunctiva and in (Conjunctival) Melanoma}

DCs are professional antigen presenting cells, which capture, process and present antigens to T-cells [197] after reaching the draining lymph nodes via the lymphatic vessels as described in Section 3. DCs link the innate and adaptive immune systems and express a high level of major histocompatibility complex (MHC) [198]. DCs develop from DC precursor cells in the bone marrow [199] and are classified into different subsets. The classification of these subsets, based on the expression of different cell surface markers [199] (Tables 3 and 4), is listed in detail below.

Table 3. Mouse DC subsets and their expressed surface markers [200-203].

\begin{tabular}{|c|c|c|c|c|c|c|c|c|}
\hline & \multicolumn{2}{|c|}{ Conventional DC } & \multicolumn{3}{|c|}{ Migratory DC } & \multirow[b]{2}{*}{$\begin{array}{c}\text { Langerhans } \\
\text { Cells }\end{array}$} & \multirow[b]{2}{*}{$\mathrm{pDC}$} & \multirow[b]{2}{*}{ moDC } \\
\hline & $\mathrm{cDC}_{1}$ & $\mathrm{cDC}_{2}$ & $\begin{array}{l}\text { CD103+ } \\
\text { CD11b- }\end{array}$ & $\begin{array}{l}\text { CD103- } \\
\text { CD11b+ }\end{array}$ & $\begin{array}{l}\text { CD103+ } \\
\text { CD11b+ }\end{array}$ & & & \\
\hline $\begin{array}{c}\text { Expressed } \\
\text { surface } \\
\text { markers }\end{array}$ & $\begin{array}{c}\text { CD11c+++ } \\
\text { CD45R- } \\
\text { MHC II++ } \\
\text { CD8 } \alpha+ \\
\text { CD11b+ } \\
\text { Sirp } \alpha+ \\
\text { CD24++ } \\
\text { CD26+ } \\
\text { XCR1+ } \\
\text { CD205++ }\end{array}$ & $\begin{array}{c}\text { CD11c+++ } \\
\text { CD45R+ } \\
\text { MHC II+ } \\
\text { CD8 } \alpha- \\
\text { CD11b+ } \\
\text { CD24+ } \\
\text { CD26+ } \\
\text { XCR1- } \\
\text { CD172 } \alpha++ \\
\text { CD205+ }\end{array}$ & $\begin{array}{c}\text { CD11c+ } \\
\text { CD103++ } \\
\text { CD11b- } \\
\text { MHC II++ } \\
\text { CD209 } \\
\text { (dc-sign)- } \\
\text { CD172 } \alpha- \\
\text { Ly6c- }\end{array}$ & $\begin{array}{c}\text { CD11c+ } \\
\text { CD103- } \\
\text { CD11b+ } \\
\text { MHC II++ } \\
\text { CD11c++ } \\
\text { CD172 } \alpha++\end{array}$ & $\begin{array}{c}\text { CD11c+ } \\
\text { CD103++ } \\
\text { CD11b+ } \\
\text { MHC II++ } \\
\text { CD11c++ } \\
\text { CD209 } \\
\text { (dc-sign)+ } \\
\text { Ly6c- } \\
\text { CD172 } \alpha-\end{array}$ & $\begin{array}{c}\text { CD45+ } \\
\text { CD11c++ } \\
\text { MHC II++ } \\
\text { CD11b+ } \\
\text { CD8- } \\
\text { CD24++ } \\
\text { CD205++ } \\
\text { CX }_{3} \text { CR1+ } \\
\text { CD172 } \alpha+ \\
\text { F4/80+ }\end{array}$ & $\begin{array}{c}\text { CD11c+ } \\
\text { CD45RA+++ } \\
\text { CD45R+++ } \\
\text { CD317+ } \\
\text { MHC II+ } \\
\text { CD172 } \alpha+ \\
\text { CD11b- } \\
\text { CD209 } \\
\text { (dc-sign)++ } \\
\text { Ly6c++ }\end{array}$ & $\begin{array}{c}\text { MHC II+ } \\
\text { CD11b+ } \\
\text { CD11c+ } \\
\text { Ly6c+ } \\
\text { F4/80+ } \\
\text { FceRI+ } \\
\text { CD209 } \\
\text { (dc-sign)+ } \\
\text { CD64+ }\end{array}$ \\
\hline
\end{tabular}

Table 4. Human DC subsets and their expressed surface marker [194,196-198].

\begin{tabular}{|c|c|c|c|c|c|c|c|}
\hline & \multicolumn{2}{|c|}{ Conventional DC } & \multicolumn{2}{|c|}{ Migratory DC } & \multirow{2}{*}{$\begin{array}{l}\text { Langerhans } \\
\text { Cells }\end{array}$} & \multirow{2}{*}{$\mathrm{pDC}$} & \multirow{2}{*}{ moDC } \\
\hline & $\mathrm{cDC}_{1}$ & $\mathrm{cDC}_{2}$ & CD1a- CD14+ & CD1a+ CD14- & & & \\
\hline $\begin{array}{l}\text { Expressed } \\
\text { surface } \\
\text { markers }\end{array}$ & $\begin{array}{c}\text { HLA-DR+ } \\
\text { CD11c+ } \\
\text { CD11b- } \\
\text { SIRP } \alpha- \\
\text { CD141+ } \\
\text { CLEC9A+ } \\
\text { XCR1+ }\end{array}$ & $\begin{array}{c}\text { HLA-DR+ } \\
\text { CD11c+++ } \\
\text { CD123- } \\
\text { SIRP } \alpha+ \\
\text { CD1c+ } \\
\text { CLEC9A- } \\
\text { BDCA1+ }\end{array}$ & $\begin{array}{c}\text { Lin- } \\
\text { HLA-DR+ } \\
\text { CD11c+ } \\
\text { CD1a- } \\
\text { CD14+ } \\
\text { BDCA1+ } \\
\text { LANGERIN- } \\
\text { CD163- } \\
\text { EpCAM- }\end{array}$ & $\begin{array}{c}\text { Lin- } \\
\text { HLA-DR+ } \\
\text { CD11c+ } \\
\text { CD1a+ } \\
\text { CD14- } \\
\text { BDCA1+ } \\
\text { LANGERIN- } \\
\text { EpCAM- } \\
\text { SIRP } \alpha+\end{array}$ & $\begin{array}{c}\text { Lin- } \\
\text { HLA-DR+ } \\
\text { CD11c+ } \\
\text { CD1a+ } \\
\text { CD14- } \\
\text { BDCA1+ } \\
\text { LANGERIN+ } \\
\text { E-CADH+ } \\
\text { SIRP } \alpha+\end{array}$ & $\begin{array}{c}\text { Lin- } \\
\text { BDCA2+ } \\
\text { BDCA4+ } \\
\text { HLA-DR+ } \\
\text { MHC II+ } \\
\text { CD1a- }\end{array}$ & $\begin{array}{c}\text { HLA-DR+ } \\
\text { CD11c+ } \\
\text { BDCA1+ } \\
\text { CD1a+ } \\
\text { FceRI+ } \\
\text { CD11b+ } \\
\text { CD172 } \alpha+ \\
\text { CD206+ } \\
\text { CD14+ }\end{array}$ \\
\hline
\end{tabular}




\subsection{Lymphoid Conventional Dendritic Cells}

The main function of conventional DCs (cDCs) is antigen presentation [204]. Their precursor cells leave the bone marrow and migrate to peripheral secondary lymphoid organs like the spleen and lymph nodes [204]. cDCs are subdivided into two subsets, $\mathrm{cDC}_{1}$ and $\mathrm{CDC}_{2}$.

\subsection{1. $\mathrm{cDC}_{1}$}

In mice, lymphoid $\mathrm{cDC}_{1}$ express toll-like receptor 2, 3, 4, 9, 11, 12 and 13 (also called pathogen recognition receptors PRRs) and recognize pathogen associated molecular patterns (PAMPs) $[205,206]$. cDC 1 are the main producers of interleukin 12 (IL-12), interferon $\alpha$ (IFN- $\alpha$ ) and IFN- $\lambda$ and also express IL- 6 and tumor necrosis factor $\alpha$ (TNF- $\alpha$ ) when they are activated by PRRs $[199,207] . \mathrm{CDC}_{1}$ in mice recognize exogenous soluble and cell-associated antigens which they present to CD8+ T-cells on MHCI [208,209]. They recognize apoptotic and necrotic cells, via Clec9A and present their antigens to cytotoxic CD8+ T-cells [210-212].

In the tumor context, $\mathrm{cDC}_{1}$ are also specialized to take up material from dead tumor cells and transport it to tumor-draining lymph nodes where they present it to anti-tumor CD8+ T-cells $[213,214]$.

Although in skin melanoma, the amount of $\mathrm{cDC}_{1}$ cells is low, e.g., in $\operatorname{tg}(\mathrm{Grm} 1) \mathrm{EPv}$ mice, the amount of $\mathrm{CDC}_{1}$ positive cells in skin melanomas was less than $1 \%$ of the $\mathrm{CD} 45+$ cells, compared to more than $2 \% \mathrm{CDC}_{2}$ and about $8 \%$ Langerhans cells [215], $\mathrm{CDC}_{1}$ still had important anti-tumoral effects. Intratumoral $\mathrm{cDC}_{1}$ can attract T-cells [216], stimulate and expand CD8+ T-cells [217] and secrete IL-12 [218]. In Batf3 ${ }^{-/-}$mice, $\mathrm{CDC}_{1}$ are missing and this leads to a failure to reject immunogenic tumors and a worse response to immune checkpoint therapies $[214,216,217,219]$.

Human CDC $_{1}$ express TLR1, 3, 6, 8 and 10 [200,220,221]. As in mice, human $\mathrm{CDC}_{1}$ are the main producers of type 3 interferon and cross-present antigens to cytotoxic T-cells [222]. In contrast to mice, human $\mathrm{cDC}_{1}$ are able to stimulate allogeneic or autologous T-helper cells [223].

\subsection{2. $\mathrm{CDC}_{2}$}

Lymphoid $\mathrm{cDC}_{2}$ in mice present pathogens on MHCII molecules [200,224]. $\mathrm{CDC}_{2}$ in the spleen detect pathogens within the cytoplasm and express TLR $1,2,4,5,6,7,8$, and $9[205,206]$. Induced by activated TLR, CDC $_{2}$ express proinflammatory cytokines like TNF- $\alpha$, IL-6 and low levels of IL-10 and play an important role in chemo attraction [199,225].

$\mathrm{CDC}_{2}$ can be subdivided in $\mathrm{ESAM}^{\mathrm{hi}}\left(80 \%\right.$ of $\left.\mathrm{CDC}_{2}\right)$, which are more efficient in $\mathrm{Th}_{2}$ polarization and in $\mathrm{ESAM}^{\mathrm{lo}}[226,227] \mathrm{CDC}_{2}$, which prime $\mathrm{Th}_{1}$ cells more efficiently $[199,227]$.

Human $\mathrm{CDC}_{2}$ are among others $C D 11 \mathrm{c}^{\text {hi }}$ SIRP $\alpha^{+}$and can be subdivided into $C D 5^{\text {hi }}$ and $\mathrm{CD}^{\text {lo }} \mathrm{CDC}_{2}[200,228]$. CD5 ${ }^{\text {hi }}$ DCs showed better migration to the lymph node and induce more potently T-cell proliferation, compared to $\mathrm{CD}^{\mathrm{lo}} \mathrm{cDC}_{2}$ [229], indicating contrasting roles in tolerance and immunity.

In the peripheral blood of melanoma patients, no significant difference was seen regarding disease stage and CD11b+ DCs [230]. In a transgenic tg(Grm1)EPv melanoma mouse strain, the amount of $\mathrm{cDC}_{2}$ decreased in the skin melanoma compared to the tumor free tissue over time, whereas no difference was seen for Langerhans cells (LCs) and $\mathrm{cDC}_{1}$ [215]. Binnewies et al. showed that in mice and humans, that CD11b+ $\mathrm{cDC} 2$ and BDCA- $1+\mathrm{CDC}_{2}$ are important to induce a protective antitumor $\mathrm{CD} 4^{+} \mathrm{T}$-cell immune response and may act as a target of T-reg suppression [224].

\subsection{Migratory Dendritic Cells ( $m D C s)$}

Tissue migratory or non-lymphoid DCs in mice can be subdivided into three main subsets: CD103++ CD11b- mDCs, CD103- CD11b+ mDCs and CD103++ CD11b+ (intestinal DCs) [200]. Further expressed markers are listed in Table 3. The CD103+ CD11b- subset has the same origin and function as $\mathrm{CDC}_{1}$ and are found mainly in connective tissues [231]. The intestinal DCs are found in the Peyer's patches [232]. CD103- CD11b+ DCs consists of 
a mixture of tissue DCs and macrophages [200]. Tissue-migratory DCs play a role in tissue immune responses and migrate via CCR7 to T-cell areas in the lymph node [171,200,233]. In human, non-lymphoid migratory DCs are subdivided in two subsets: CD1a- CD14+ CD163- and CD1a+ CD14- SIRP $\alpha+$, which are located in the dermis [200].

In mouse skin melanoma models, CD103+ CD11b+ cells have been shown to be the only antigen presenting cells, transporting tumor antigen to the lymph nodes and subsequently priming CD8+ T-cells, although they represent only a minor population of DCs infiltrating the tumor [214]. They were further necessary to promote an anti-tumoral effect upon blockade of PDL-1 and could be systemically expanded by Flt3L with a tumor protective effect [214].

\subsection{Langerhans Cells (LCS)}

LCs are found in the epidermal layer of the skin, in the epithelium of the cornea, buccal, gingival and genital mucosae and lead to regulatory T-cell proliferation in a steady state, but limit the activation in an inflamed state [234,235].

Human LCs are among others LANGERIN+ [200]. In humans, LCs are producers of IL-15 [236]. They are able to present antigens to cytotoxic CD8 ${ }^{+} \mathrm{T}$-cells, to $\mathrm{Th}_{17}$ and $\mathrm{Th}_{22}$ cells [236-238]. In different mucosal tissues, there were highly site dependent differences in the amount of LCs, when comparing the amount of LC in the conjunctiva, oral mucosa, anus and penis [239].

\subsection{Plasmacytoid Dendritic Cells ( $p D C s$ )}

pDCs are the major producers of type 1 interferons $[199,204]$ and have anti-proliferative and antiviral functions [240]. pDCs develop in the bone marrow and afterward circulate in the blood and migrate to peripheral organs [202,241].

pDCs in mice are CD317+ CD209++ Ly6c++ [200,202]. TLR7, TLR9 and TLR12 are highly expressed by pDCs [205]. pDCs upregulate MHC II and produce type I (IFN- $\alpha$, IFN- $\beta$ ) and III interferons (IFN- $\lambda$ ), which affect cDCs, NK cells, CD4 ${ }^{+}$T-helper cells and cytotoxic T-cells to lead to an anti-viral immune response [202,242].

Human pDCs, like murine pDCs, respond to viral infections and produce type 1 interferon in response to TLR7 and TLR9 and type 3 interferons in response to TLR9 [243,244]. The presence of pDCs in tumors is correlated with a worse outcome because they promote the expansion of T-reg populations, which inhibit the anti-tumor immunity [243]. Low pDCs levels in the peripheral blood of melanoma patients were correlated with advanced or active melanoma [230].

Others showed that human pDCs are more efficient in attracting cytotoxic CD8+ T-cells than $\mathrm{CDC}_{2}$ in melanoma patients receiving $\mathrm{DC}$ vaccination [245]. Interfering with $\mathrm{pDC}$ function has led to therapeutic innovations in skin cancers like basal cell carcinoma. The TLR7 ligand Imiquimod has been approved for local treatment and promotes pDCs and induces cytotoxicity [246].

\subsection{Monocyte Derived Inflammatory Dendritic Cells (moDCs)}

moDCs originate from monocytes and appear in inflammation, cancer, or infection $[203,237,247]$. moDCs act at the site of inflammation and stimulate CD4 ${ }^{+}$and CD8 ${ }^{+}$ T-cells due to the secretion of IL-1, IL-12, IL-23 and TNF- $\alpha[237,248]$.

\subsection{Dendritic Cells in Healthy Conjunctiva and during Conjunctival Pathologies}

In general, little is known about DC subsets in the conjunctiva per se and in CM. However, a few DC subsets have been described in the healthy conjunctiva: Ohbayashi et al. used confocal microscopy for detecting DCs in the conjunctiva and found a small number of conventional DCs but almost no plasmacytoid DCs (pDCs) [249]. Langerhans cells (LCs) were also absent from the conjunctival epithelium [249]. In contrast, Jamali et al. (2020) reported a population of pDCs in the bulbar conjunctiva [250]. In pigmented conjunctival lesions, DCs have been detected using in vivo confocal microscopy [251,252]. 
A subset differentiation was not possible using this technique. Older studies identified LCs in the conjunctiva at a density of up to 300 cells $/ \mathrm{mm}^{2}$ [253] and with a decline in the LC density corresponding to the advancing age of tissue donors. Most LCs were found in the palpebral conjunctiva [254]. Khandewal et al. could show in the mouse that CD103+ as well as CD11b+ DC are present in the healthy conjunctiva and induce allergic responses [255] via CCR7 [256].

DCs play also an important role in the development of autoimmune diseases of the ocular surface like dry eye disease. It was shown that Thrombospondin-1 (TSP-1) is expressed on DCs of the ocular surface [257].

Additionally, in infectious diseases, DCs play a critical role by presenting pathogenic antigens to effector T-cells. For the conjunctiva, it was recently shown that goblet cells, which provide the mucin layer of the tear film, are in close contact with conjunctival DC. Contreras-Ruiz et al. could show that, on one hand, goblet cells control the activation status of conjunctival DC by expression of TGF- $\beta 2$ and TSP-1 inducing a tolerogenic phenotype [13]. On the other hand, they could show that goblet cells responding to TLR5 engagement activate conjunctival DC, which subsequently extend their intra-epithelial dendrites and upregulate MHC class II [258].

In pterygium, a benign conjunctival tumor that centripetally invades the clear cornea, laser scanning confocal microscopy revealed in patients that in both the clear cornea, as well as in the pterygium, the amount of DCs was significantly increased [259]. An Australian study analyzed the predictive value of pterygia for cutaneous melanoma and found significantly more cases of cutaneous melanoma in patients with pterygium compared to the control cohort [259].

In malignant CM, Wolf et al. recently characterized the tumor microenvironment of CM in more detail. Next to natural killer T-cells (NKT), B-cells and mast cells, they found an enrichment of pDC and activated DCs in CM compared to healthy conjunctiva [260]. For pDCs it is known that they originally contribute a strong IFN $\gamma$ response within the innate and adaptive immune response. In tumorigenesis, in contrast, pDCs produce less IFN $\gamma$ and contribute to an immunosuppressive tumor microenvironment (TME), as summarized elsewhere [261].

In the field of skin melanoma, more is known about the DC subtypes. Here three major subsets of $\mathrm{CD}_{11 \mathrm{c}^{+}} \mathrm{MHCII}^{+} \mathrm{DC}$ have been identified in the tumor microenvironment: $\mathrm{cDC}_{1}, \mathrm{cDC}_{2}$ and moDCs [262-264].

In several studies of human melanomas, a low number of intratumoral DCs have been associated with a worse prognosis $[265,266]$.

Wculek et al. reviewed that tumor-associated DCs, for example, in ovarian cancer, cutaneous melanoma, gastric cancer and lung carcinoma have a reduced function in differentiation, activation and stimulation of immune response [216,243,267-269].

\section{Summary}

$\mathrm{CM}$ is a very rare tumor with a high rate of mortality and local recurrence. Despite some similarities with cutaneous melanoma, CM is a mucosal melanoma and only very little is known about immunological responses or DC subsets in CM. Promising new therapeutic options are targeted molecular inhibitors, immune checkpoint inhibitors and DC-immunotherapy. Although more and more knowledge about DCs and their subtypes is becoming known and single studies have shown effects of different DC subtypes in several diseases of the ocular surface, unfortunately very little is known about the subtypes in CM so far. Whether individual subtypes are important and similar to other cancer types, should be shown by future studies to exploit possible therapeutic effects.

Therefore, much remains to be learned about the composition and function of DCs and their subsets in CM to establish new therapy options.

Funding: This research was funded by SLS: DFG SCHL 2157/2-1, Center for Molecular Medicine Cologne, FK: DFG SFB1348/1-386797833/SFB1450/1-431460824, CC: www.FOR2240.de. 
Conflicts of Interest: The authors declare no conflict of interest.

\section{References}

1. Van Poppelen, N.M.; Yavuzyigitoglu, S.; Smit, K.N.; Vaarwater, J.; Eussen, B.; Brands, T.; Paridaens, D.; Kiliç, E.; de Klein, A. Chromosomal rearrangements in uveal melanoma: Chromothripsis. Genes Chromosomes Cancer 2018, 57, 452-458. [CrossRef]

2. Shain, A.H.; Bagger, M.M.; Yu, R.; Chang, D.; Liu, S.; Vemula, S.; Weier, J.F.; Wadt, K.; Heegaard, S.; Bastian, B.C.; et al. The genetic evolution of metastatic uveal melanoma. Nat. Genet. 2019, 51, 1123-1130. [CrossRef] [PubMed]

3. Alvarez-Rodriguez, B.; Latorre, A.; Posch, C.; Somoza, A. Recent advances in uveal melanoma treatment. Med. Res. Rev. 2017, 37, 1350-1372. [CrossRef] [PubMed]

4. Ortega, M.A.; Fraile-Martinez, O.; Garcia-Honduvilla, N.; Coca, S.; Alvarez-Mon, M.; Bujan, J.; Teus, M.A. Update on uveal melanoma: Translational research from biology to clinical practice (Review). Int. J. Oncol. 2020, 57, 1262-1279. [CrossRef] [PubMed]

5. Seregard, S. Conjunctival melanoma. Surv. Ophthalmol. 1998, 42, 321-350. [CrossRef]

6. Iwamoto, S.; Burrows, R.C.; Grossniklaus, H.E.; Orcutt, J.; Kalina, R.E.; Boehm, M.; Bothwell, M.A.; Schmidt, R. Immunophenotype of Conjunctival Melanomas: Comparisons With Uveal and Cutaneous Melanomas. Arch. Ophthalmol. 2002, 120, 1625-1629. [CrossRef]

7. Stern, C.D. Neural induction: Old problem, new findings, yet more questions. Development 2005, 132, 2007-2021. [CrossRef]

8. Wotherspoon, A.C.; Hardman-Lea, S.; Isaacson, P.G. Mucosa-associated lymphoid tissue (MALT) in the human conjunctiva. J. Pathol. 1994, 174, 33-37. [CrossRef]

9. Ono, S.; Kabashima, K. Novel insights into the role of immune cells in skin and inducible skin-associated lymphoid tissue (iSALT). Allergo J. Int. 2015, 24, 170-179. [CrossRef]

10. Shumway, C.L.; Motlagh, M.; Wade, M. Anatomy, Head and Neck, Eye Conjunctiva. In StatPearls; StatPearls Publishing LLC.: Treasure Island, FL, USA, 2021.

11. Mikkelsen, L.H. Molecular biology in conjunctival melanoma and the relationship to mucosal melanoma. Acta Ophthalmol. 2020, 98, 1-27. [CrossRef]

12. Gipson, I.K.; Argüeso, P. Role of mucins in the function of the corneal and conjunctival epithelia. Int. Rev. Cytol. 2003, 231, 1-49.

13. Contreras-Ruiz, L.; Masli, S. Immunomodulatory cross-talk between conjunctival goblet cells and dendritic cells. PLoS ONE 2015, 10, e0120284. [CrossRef]

14. Johansson, M.E.; Hansson, G.C. Immunological aspects of intestinal mucus and mucins. Nat. Rev. Immunol. 2016, 16, 639-649. [CrossRef] [PubMed]

15. Pflugfelder, S.C.; de Paiva, C.S. Goblet cells promote tolerance induction in the conjunctiva. Mucosal Immunol. 2020, 13, 717-718. [CrossRef] [PubMed]

16. Guy, G.P., Jr.; Thomas, C.C.; Thompson, T.; Watson, M.; Massetti, G.M.; Richardson, L.C.; Centers for Disease Control and Prevention (CDC). Prevention, Vital signs: Melanoma incidence and mortality trends and projections-United States, $1982-2030$. MMWR Morb. Mortal. Wkly. Rep. 2015, 64, 591-596. [PubMed]

17. Kaštelan, S.; Gverović Antunica, A.; Beketić Orešković, L.; Salopek Rabatić, J.; Kasun, B.; Bakija, I. Conjunctival MelanomaEpidemiological Trends and Features. Pathol. Oncol. Res. 2018, 24, 787-796. [CrossRef] [PubMed]

18. McLaughlin, C.C.; Wu, X.C.; Jemal, A.; Martin, H.J.; Roche, L.M.; Chen, V.W. Incidence of noncutaneous melanomas in the U.S. Cancer 2005, 103, 1000-1007. [CrossRef] [PubMed]

19. Inskip, P.D.; Devesa, S.S.; Fraumeni, J.F., Jr. Trends in the incidence of ocular melanoma in the United States, 1974-1998. Cancer Causes Control 2003, 14, 251-257. [CrossRef]

20. Grimes, J.M.; Shah, N.V.; Samie, F.H.; Carvajal, R.D.; Marr, B.P. Conjunctival Melanoma: Current Treatments and Future Options. Am. J. Clin. Dermatol. 2020, 21, 371-381. [CrossRef]

21. Colombino, M.; Lissia, A.; Franco, R.; Botti, G.; Ascierto, P.A.; Manca, A.; Sini, M.C.; Pisano, M.; Paliogiannis, P.; Tanda, F.; et al. Unexpected distribution of cKIT and BRAF mutations among southern Italian patients with sinonasal melanoma. Dermatology 2013, 226, 279-284. [CrossRef]

22. Hu, D.N.; Yu, G.; McCormick, S.A.; Finger, P.T. Population-based incidence of conjunctival melanoma in various races and ethnic groups and comparison with other melanomas. Am. J. Ophthalmol. 2008, 145, 418-423. [CrossRef] [PubMed]

23. Park, S.J.; Oh, C.M.; Kim, B.W.; Woo, S.J.; Cho, H.; Park, K.H. Nationwide Incidence of Ocular Melanoma in South Korea by Using the National Cancer Registry Database (1999-2011). Investig. Ophthalmol. Vis. Sci. 2015, 56, 4719-4724. [CrossRef] [PubMed]

24. Kao, A.; Afshar, A.; Bloomer, M.; Damato, B. Management of Primary Acquired Melanosis, Nevus, and Conjunctival Melanoma. Cancer Control 2016, 23, 117-125. [CrossRef] [PubMed]

25. Beaudoux, O.; Riffaud, L.; Barbe, C.; Grange, F. Prognostic factors and incidence of primary mucosal melanoma: A populationbased study in France. Eur. J. Dermatol. 2018, 28, 654-660.

26. Ghazawi, F.M.; Darwich, R.; Le, M.; Jfri, A.; Rahme, E.; Burnier, J.V.; Sasseville, D.; Burnier, M.N., Jr.; Litvinov, I.V. Incidence trends of conjunctival malignant melanoma in Canada. Br. J. Ophthalmol. 2020, 104, 23-25. [CrossRef]

27. Brouwer, N.J.; Verdijk, R.M.; Heegaard, S.; Marinkovic, M.; Esmaeli, B.; Jager, M.J. Conjunctival melanoma: New insights in tumour genetics and immunology, leading to new therapeutic options. Prog. Retin. Eye Res. 2021, 86, 100971. [CrossRef] 
28. Shields, C.L.; Demirci, H.; Karatza, E.; Shields, J.A. Clinical survey of 1643 melanocytic and nonmelanocytic conjunctival tumors. Ophthalmology 2004, 111, 1747-1754. [CrossRef]

29. Larsen, A.C. Conjunctival malignant melanoma in Denmark: Epidemiology, treatment and prognosis with special emphasis on tumorigenesis and genetic profile. Acta Ophthalmol. 2016, 94, 1-27. [CrossRef]

30. Tuomaala, S.; Eskelin, S.; Tarkkanen, A.; Kivela, T. Population-based assessment of clinical characteristics predicting outcome of conjunctival melanoma in whites. Investig. Ophthalmol. Vis. Sci. 2002, 43, 3399-3408.

31. Virgili, G.; Gatta, G.; Ciccolallo, L.; Capocaccia, R.; Biggeri, A.; Crocetti, E.; Lutz, J.M.; Paci, E. Incidence of uveal melanoma in Europe. Ophthalmology 2007, 114, 2309-2315. [CrossRef]

32. Shields, C.L.; Shields, J.A.; Gunduz, K.; Cater, J.; Mercado, G.V.; Gross, N.; Lally, B. Conjunctival melanoma: Risk factors for recurrence, exenteration, metastasis, and death in 150 consecutive patients. Arch. Ophthalmol. 2000, 118, 1497-1507. [CrossRef] [PubMed]

33. Jakobiec, F.A.; Folberg, R.; Iwamoto, T. Clinicopathologic characteristics of premalignant and malignant melanocytic lesions of the conjunctiva. Ophthalmology 1989, 96, 147-166. [CrossRef]

34. Gandini, S.; Sera, F.; Cattaruzza, M.S.; Pasquini, P.; Zanetti, R.; Masini, C.; Boyle, P.; Melchi, C.F. Meta-analysis of risk factors for cutaneous melanoma: III. Family history, actinic damage and phenotypic factors. Eur. J. Cancer 2005, 41, 2040-2059. [CrossRef] [PubMed]

35. Thomas, N.E.; Edmiston, S.N.; Alexander, A.; Millikan, R.C.; Groben, P.A.; Hao, H.; Tolbert, D.; Berwick, M.; Busam, K.; Begg, C.B.; et al. Number of nevi and early-life ambient UV exposure are associated with BRAF-mutant melanoma. Cancer Epidemiol. Biomark. Prev. 2007, 16, 991-997. [CrossRef]

36. Cooper, C.; Sorrell, J.; Gerami, P. Update in molecular diagnostics in melanocytic neoplasms. Adv. Anat. Pathol. 2012, 19, 410-416. [CrossRef]

37. Paszkowska-Szczur, K.; Scott, R.J.; Serrano-Fernandez, P.; Mirecka, A.; Gapska, P.; Górski, B.; Cybulski, C.; Maleszka, R.; Sulikowski, M.; Nagay, L.; et al. Xeroderma pigmentosum genes and melanoma risk. Int. J. Cancer 2013, 133, 1094-1100. [CrossRef]

38. Braam, K.I.; Overbeek, A.; Kaspers, G.J.; Ronckers, C.M.; Schouten-van Meeteren, A.Y.; Van Dulmen-Den Broeder, E.; Veening, M.A. Malignant melanoma as second malignant neoplasm in long-term childhood cancer survivors: A systematic review. Pediatr. Blood Cancer 2012, 58, 665-674. [CrossRef]

39. Vasanthapuram, V.H.; Kaliki, S. Conjunctival melanoma in patients with xeroderma pigmentosum: A series of four cases. Int Ophthalmol. 2020, 40, 1143-1146. [CrossRef]

40. Griewank, K.G.; Westekemper, H.; Murali, R.; Mach, M.; Schilling, B.; Wiesner, T.; Schimming, T.; Livingstone, E.; Sucker, A.; Grabellus, F.; et al. Conjunctival melanomas harbor BRAF and NRAS mutations and copy number changes similar to cutaneous and mucosal melanomas. Clin. Cancer Res. 2013, 19, 3143-3152. [CrossRef]

41. Griewank, K.G.; Murali, R.; Schilling, B.; Scholz, S.; Sucker, A.; Song, M.; Süsskind, D.; Grabellus, F.; Zimmer, L.; Hillen, U.; et al. TERT promoter mutations in ocular melanoma distinguish between conjunctival and uveal tumours. Br. J. Cancer 2013, 109, 497-501. [CrossRef]

42. Swaminathan, S.S.; Field, M.G.; Sant, D.; Wang, G.; Galor, A.; Dubovy, S.R.; Harbour, J.W.; Karp, C.L. Molecular Characteristics of Conjunctival Melanoma Using Whole-Exome Sequencing. JAMA Ophthalmol. 2017, 135, 1434-1437. [CrossRef] [PubMed]

43. Spencer, K.R.; Mehnert, J.M. Mucosal Melanoma: Epidemiology, Biology and Treatment. In Melanoma; Kaufman, H.L., Mehnert, J.M., Eds.; Springer International Publishing: Cham, Switzerland, 2016; pp. 295-320.

44. Dahlgren, L.; Schedvins, K.; Kanter-Lewensohn, L.; Dalianis, T.; Ragnarsson-Olding, B.K. Human papilloma virus (HPV) is rarely detected in malignant melanomas of sun sheltered mucosal membranes. Acta Oncol. 2005, 44, 694-699. [CrossRef] [PubMed]

45. Lundberg, R.; Brytting, M.; Dahlgren, L.; Kanter-Lewensohn, L.; Schloss, L.; Dalianis, T.; Ragnarsson-Olding, B. Human herpes virus DNA is rarely detected in non-UV light-associated primary malignant melanomas of mucous membranes. Anticancer Res. 2006, 26, 3627-3631. [PubMed]

46. Giraud, G.; Ramqvist, T.; Ragnarsson-Olding, B.; Dalianis, T. DNA from BK virus and JC virus and from KI, WU, and MC polyomaviruses as well as from simian virus 40 is not detected in non-UV-light-associated primary malignant melanomas of mucous membranes. J. Clin. Microbiol. 2008, 46, 3595-3598. [CrossRef]

47. Axéll, T.; Hedin, C.A. Epidemiologic study of excessive oral melanin pigmentation with special reference to the influence of tobacco habits. Scand. J. Dent. Res. 1982, 90, 434-442.

48. Holmstrom, M.; Lund, V.J. Malignant melanomas of the nasal cavity after occupational exposure to formaldehyde. Br. J. Ind. Med. 1991, 48, 9-11. [CrossRef]

49. Thompson, L.D.; Wieneke, J.A.; Miettinen, M. Sinonasal tract and nasopharyngeal melanomas: A clinicopathologic study of 115 cases with a proposed staging system. Am. J. Surg. Pathol. 2003, 27, 594-611. [CrossRef]

50. Damato, B.; Coupland, S.E. Conjunctival melanoma and melanosis: A reappraisal of terminology, classification and staging. Clin. Exp. Ophthalmol. 2008, 36, 786-795. [CrossRef]

51. Missotten, G.S.; Keijser, S.; De Keizer, R.J.; De Wolff-Rouendaal, D. Conjunctival melanoma in the Netherlands: A nationwide study. Investig. Ophthalmol. Vis. Sci. 2005, 46, 75-82. [CrossRef]

52. Brownstein, S. Malignant melanoma of the conjunctiva. Cancer Control 2004, 11, 310-316. [CrossRef] 
53. Wong, J.R.; Nanji, A.A.; Galor, A.; Karp, C.L. Management of conjunctival malignant melanoma: A review and update. Expert Rev. Ophthalmol. 2014, 9, 185-204. [CrossRef] [PubMed]

54. The Cancer Genome Atlas Network. Genomic Classification of Cutaneous Melanoma. Cell 2015, 161, 1681-1696. [CrossRef] [PubMed]

55. Hodis, E.; Watson, I.R.; Kryukov, G.V.; Arold, S.T.; Imielinski, M.; Theurillat, J.P.; Nickerson, E.; Auclair, D.; Li, L.; Place, C.; et al. A landscape of driver mutations in melanoma. Cell 2012, 150, 251-263. [CrossRef] [PubMed]

56. Goydos, J.S.; Mann, B.; Kim, H.J.; Gabriel, E.M.; Alsina, J.; Germino, F.J.; Shih, W.; Gorski, D.H. Detection of B-RAF and N-RAS mutations in human melanoma. J. Am. Coll Surg. 2005, 200, 362-370. [CrossRef]

57. Spendlove, H.E.; Damato, B.E.; Humphreys, J.; Barker, K.T.; Hiscott, P.S.; Houlston, R.S. BRAF mutations are detectable in conjunctival but not uveal melanomas. Melanoma Res. 2004, 14, 449-452. [CrossRef]

58. Gear, H.; Williams, H.; Kemp, E.G.; Roberts, F. BRAF mutations in conjunctival melanoma. Investig. Ophthalmol. Vis. Sci. 2004, 45, 2484-2488. [CrossRef]

59. McCubrey, J.A.; Steelman, L.S.; Chappell, W.H.; Abrams, S.L.; Wong, E.W.; Chang, F.; Lehmann, B.; Terrian, D.M.; Milella, M.; Tafuri, A.; et al. Roles of the Raf/MEK/ERK pathway in cell growth, malignant transformation and drug resistance. Biochim. Biophys. Acta 2007, 1773, 1263-1284. [CrossRef]

60. Rossi, E.; Schinzari, G.; Maiorano, B.A.; Pagliara, M.M.; Di Stefani, A.; Bria, E.; Peris, K.; Blasi, M.A.; Tortora, G. Conjunctival Melanoma: Genetic and Epigenetic Insights of a Distinct Type of Melanoma. Int. J. Mol. Sci. 2019, 20, 5447. [CrossRef]

61. Lake, S.L.; Jmor, F.; Dopierala, J.; Taktak, A.F.; Coupland, S.E.; Damato, B.E. Multiplex ligation-dependent probe amplification of conjunctival melanoma reveals common BRAF V600E gene mutation and gene copy number changes. Investig. Ophthalmol. Vis. Sci. 2011, 52, 5598-5604. [CrossRef]

62. Goldenberg-Cohen, N.; Cohen, Y.; Rosenbaum, E.; Herscovici, Z.; Chowers, I.; Weinberger, D.; Pe'er, J.; Sidransky, D. T1799A BRAF mutations in conjunctival melanocytic lesions. Investig. Ophthalmol. Vis. Sci. 2005, 46, 3027-3030. [CrossRef]

63. Cao, J.; Heijkants, R.C.; Jochemsen, A.G.; Dogrusoz, M.; de Lange, M.J.; van der Velden, P.A.; van der Burg, S.H.; Jager, M.J.; Verdijk, R.M. Targeting of the MAPK and AKT pathways in conjunctival melanoma shows potential synergy. Oncotarget 2017, 8, 58021-58036. [CrossRef] [PubMed]

64. Ascierto, P.A.; McArthur, G.A.; Dreno, B.; Atkinson, V.; Liszkay, G.; Di Giacomo, A.M.; Mandala, M.; Demidov, L.; Stroyakovskiy, D.; Thomas, L.; et al. Cobimetinib combined with vemurafenib in advanced BRAF(V600)-mutant melanoma (coBRIM): Updated efficacy results from a randomised, double-blind, phase 3 trial. Lancet Oncol. 2016, 17, 1248-1260. [CrossRef]

65. Gkiala, A.; Palioura, S. Conjunctival Melanoma: Update on Genetics, Epigenetics and Targeted Molecular and Immune-Based Therapies. Clin. Ophthalmol. 2020, 14, 3137-3152. [CrossRef]

66. Cantwell-Dorris, E.R.; O'Leary, J.J.; Sheils, O.M. BRAFV600E: Implications for carcinogenesis and molecular therapy. Mol. Cancer Ther. 2011, 10, 385-394. [CrossRef] [PubMed]

67. Larsen, A.-C.; Dahmcke, C.M.; Dahl, C.; Siersma, V.D.; Toft, P.B.; Coupland, S.E.; Prause, J.U.; Guldberg, P.; Heegaard, S. A Retrospective Review of Conjunctival Melanoma Presentation, Treatment, and Outcome and an Investigation of Features Associated With BRAF Mutations. JAMA Ophthalmol. 2015, 133, 1295-1303. [CrossRef] [PubMed]

68. Larsen, A.C.; Dahl, C.; Dahmcke, C.M.; Lade-Keller, J.; Siersma, V.D.; Toft, P.B.; Coupland, S.E.; Prause, J.U.; Guldberg, P.; Heegaard, S. BRAF mutations in conjunctival melanoma: Investigation of incidence, clinicopathological features, prognosis and paired premalignant lesions. Acta Ophthalmol. 2016, 94, 463-470. [CrossRef] [PubMed]

69. Kenawy, N.; Kalirai, H.; Sacco, J.J.; Lake, S.L.; Heegaard, S.; Larsen, A.C.; Finger, P.T.; Milman, T.; Chin, K.; Mosci, C.; et al. Conjunctival melanoma copy number alterations and correlation with mutation status, tumor features, and clinical outcome. Pigment. Cell Melanoma Res. 2019, 32, 564-575. [CrossRef]

70. Shain, A.H.; Yeh, I.; Kovalyshyn, I.; Sriharan, A.; Talevich, E.; Gagnon, A.; Dummer, R.; North, J.; Pincus, L.; Ruben, B.; et al. The Genetic Evolution of Melanoma from Precursor Lesions. N. Engl. J. Med. 2015, 373, 1926-1936. [CrossRef]

71. Maldonado, J.L.; Fridlyand, J.; Patel, H.; Jain, A.N.; Busam, K.; Kageshita, T.; Ono, T.; Albertson, D.G.; Pinkel, D.; Bastian, B.C. Determinants of BRAF mutations in primary melanomas. J. Natl. Cancer Inst. 2003, 95, 1878-1890. [CrossRef]

72. Hacker, E.; Hayward, N.K.; Dumenil, T.; James, M.R.; Whiteman, D.C. The association between MC1R genotype and BRAF mutation status in cutaneous melanoma: Findings from an Australian population. J. Investig. Dermatol. 2010, 130, 241-248. [CrossRef]

73. Long, G.V.; Menzies, A.M.; Nagrial, A.M.; Haydu, L.E.; Hamilton, A.L.; Mann, G.J.; Hughes, T.M.; Thompson, J.F.; Scolyer, R.A.; Kefford, R.F. Prognostic and clinicopathologic associations of oncogenic BRAF in metastatic melanoma. J. Clin. Oncol. 2011, 29, 1239-1246. [CrossRef] [PubMed]

74. Sosman, J.A.; Kim, K.B.; Schuchter, L.; Gonzalez, R.; Pavlick, A.C.; Weber, J.S.; McArthur, G.A.; Hutson, T.E.; Moschos, S.J.; Flaherty, K.T.; et al. Survival in BRAF V600-mutant advanced melanoma treated with vemurafenib. N. Engl. J. Med. 2012, 366, 707-714. [CrossRef] [PubMed]

75. Postow, M.A.; Luke, J.J.; Bluth, M.J.; Ramaiya, N.; Panageas, K.S.; Lawrence, D.P.; Ibrahim, N.; Flaherty, K.T.; Sullivan, R.J.; Ott, P.A.; et al. Ipilimumab for patients with advanced mucosal melanoma. Oncologist 2013, 18, 726-732. [CrossRef] [PubMed]

76. Zebary, A.; Jangard, M.; Omholt, K.; Ragnarsson-Olding, B.; Hansson, J. KIT, NRAS and BRAF mutations in sinonasal mucosal melanoma: A study of 56 cases. Br. J. Cancer 2013, 109, 559-564. [CrossRef] [PubMed] 
77. Omholt, K.; Grafström, E.; Kanter-Lewensohn, L.; Hansson, J.; Ragnarsson-Olding, B.K. KIT pathway alterations in mucosal melanomas of the vulva and other sites. Clin. Cancer Res. 2011, 17, 3933-3942. [CrossRef]

78. Curtin, J.A.; Busam, K.; Pinkel, D.; Bastian, B.C. Somatic activation of KIT in distinct subtypes of melanoma. J. Clin. Oncol. 2006, 24, 4340-4346. [CrossRef] [PubMed]

79. Curtin, J.A.; Fridlyand, J.; Kageshita, T.; Patel, H.N.; Busam, K.J.; Kutzner, H.; Cho, K.H.; Aiba, S.; Bröcker, E.B.; LeBoit, P.E.; et al. Distinct sets of genetic alterations in melanoma. N. Engl. J. Med. 2005, 353, 2135-2147. [CrossRef]

80. Scholz, S.L.; Cosgarea, I.; Susskind, D.; Murali, R.; Moller, I.; Reis, H.; Leonardelli, S.; Schilling, B.; Schimming, T.; Hadaschik, E.; et al. NF1 mutations in conjunctival melanoma. Br. J. Cancer 2018, 118, 1243-1247. [CrossRef]

81. Rosenbaum, T.; Wimmer, K. Neurofibromatosis type 1 (NF1) and Associated Tumors. Klin. Padiatr. 2014, 226, 309-315. [CrossRef]

82. van Ipenburg, J.A.; Naus, N.C.; Dubbink, H.J.; van Ginderdeuren, R.; Missotten, G.S.; Paridaens, D.; Verdijk, R.M. Prognostic value of TERT promoter mutations in conjunctival melanomas in addition to clinicopathological features. Br. J. Ophthalmol. 2021, $105,1454-1461$.

83. Koopmans, A.E.; Ober, K.; Dubbink, H.J.; Paridaens, D.; Naus, N.C.; Belunek, S.; Krist, B.; Post, E.; Zwarthoff, E.C.; de Klein, A.; et al. Prevalence and implications of TERT promoter mutation in uveal and conjunctival melanoma and in benign and premalignant conjunctival melanocytic lesions. Investig. Ophthalmol. Vis. Sci. 2014, 55, 6024-6030. [CrossRef] [PubMed]

84. Horn, S.; Figl, A.; Rachakonda, P.S.; Fischer, C.; Sucker, A.; Gast, A.; Kadel, S.; Moll, I.; Nagore, E.; Hemminki, K.; et al. TERT promoter mutations in familial and sporadic melanoma. Science 2013, 339, 959-961. [CrossRef] [PubMed]

85. Jangard, M.; Zebary, A.; Ragnarsson-Olding, B.; Hansson, J. TERT promoter mutations in sinonasal malignant melanoma: A study of 49 cases. Melanoma Res. 2015, 25, 185-188. [CrossRef] [PubMed]

86. Beadling, C.; Jacobson-Dunlop, E.; Hodi, F.S.; Le, C.; Warrick, A.; Patterson, J.; Town, A.; Harlow, A.; Cruz, F., 3rd; Azar, S.; et al. KIT gene mutations and copy number in melanoma subtypes. Clin. Cancer Res. 2008, 14, 6821-6828. [CrossRef] [PubMed]

87. Yuzawa, S.; Opatowsky, Y.; Zhang, Z.; Mandiyan, V.; Lax, I.; Schlessinger, J. Structural basis for activation of the receptor tyrosine kinase KIT by stem cell factor. Cell 2007, 130, 323-334. [CrossRef] [PubMed]

88. Lennartsson, J.; Rönnstrand, L. Stem Cell Factor Receptor/c-Kit: From Basic Science to Clinical Implications. Physiol. Rev. 2012, 92, 1619-1649. [CrossRef]

89. Shields, C.L.; Shields, J.A. Ocular melanoma: Relatively rare but requiring respect. Clin. Dermatol. 2009, 27, 122-133. [CrossRef]

90. Tuomaala, S.; Kivelä, T. Metastatic pattern and survival in disseminated conjunctival melanoma: Implications for sentinel lymph node biopsy. Ophthalmology 2004, 111, 816-821. [CrossRef]

91. Esmaeli, B.; Wang, X.; Youssef, A.; Gershenwald, J.E. Patterns of regional and distant metastasis in patients with conjunctival melanoma: Experience at a cancer center over four decades. Ophthalmology 2001, 108, 2101-2105. [CrossRef]

92. Shields, C.L. Conjunctival melanoma: Risk factors for recurrence, exenteration, metastasis, and death in 150 consecutive patients. Trans. Am. Ophthalmol. Soc. 2000, 98, 471-492. [CrossRef]

93. Salcedo-Hernandez, R.A.; Luna-Ortiz, K.; Lino-Silva, L.S.; Herrera-Gomez, A.; Villavicencio-Valencia, V.; Tejeda-Rojas, M.; Carrillo, J.F. Conjunctival melanoma: Survival analysis in twenty-two Mexican patients. Arq. Bras. Oftalmol. 2014, 77, 155-158. [CrossRef] [PubMed]

94. Tuomaala, S.; Kivela, T. Conjunctival melanoma: Is it increasing in the United States? Am. J. Ophthalmol. 2003, 136, 1189-1190, author reply 1190. [CrossRef] [PubMed]

95. Vora, G.K.; Demirci, H.; Marr, B.; Mruthyunjaya, P. Advances in the management of conjunctival melanoma. Surv. Ophthalmol. 2017, 62, 26-42. [CrossRef] [PubMed]

96. Garbe, C.; Amaral, T.; Peris, K.; Hauschild, A.; Arenberger, P.; Bastholt, L.; Bataille, V.; Del Marmol, V.; Dreno, B.; Fargnoli, M.C.; et al. European consensus-based interdisciplinary guideline for melanoma. Part 2: Treatment-Update 2019. Eur. J. Cancer 2020, 126, 159-177. [CrossRef] [PubMed]

97. Weber, J.; Mandala, M.; Del Vecchio, M.; Gogas, H.J.; Arance, A.M.; Cowey, C.L.; Dalle, S.; Schenker, M.; Chiarion-Sileni, V.; Marquez-Rodas, I.; et al. Adjuvant Nivolumab versus Ipilimumab in Resected Stage III or IV Melanoma. N. Engl. J. Med. 2017, 377, 1824-1835. [CrossRef]

98. Eggermont, A.M.M.; Blank, C.U.; Mandala, M.; Long, G.V.; Atkinson, V.; Dalle, S.; Haydon, A.; Lichinitser, M.; Khattak, A.; Carlino, M.S.; et al. Adjuvant Pembrolizumab versus Placebo in Resected Stage III Melanoma. N. Engl. J. Med. 2018, 378, 1789-1801. [CrossRef]

99. Long, G.V.; Hauschild, A.; Santinami, M.; Atkinson, V.; Mandala, M.; Chiarion-Sileni, V.; Larkin, J.; Nyakas, M.; Dutriaux, C.; Haydon, A.; et al. Adjuvant Dabrafenib plus Trametinib in Stage III BRAF-Mutated Melanoma. N. Engl. J. Med. 2017, 377, 1813-1823. [CrossRef]

100. Larkin, J.; Ascierto, P.A.; Dréno, B.; Atkinson, V.; Liszkay, G.; Maio, M.; Mandalà, M.; Demidov, L.; Stroyakovskiy, D.; Thomas, L.; et al. Combined Vemurafenib and Cobimetinib in BRAF-Mutated Melanoma. N. Engl. J. Med. 2014, 371, 1867-1876. [CrossRef]

101. Chapman, P.B.; Hauschild, A.; Robert, C.; Haanen, J.B.; Ascierto, P.; Larkin, J.; Dummer, R.; Garbe, C.; Testori, A.; Maio, M.; et al. Improved Survival with Vemurafenib in Melanoma with BRAF V600E Mutation. N. Engl. J. Med. 2011, 364, 2507-2516. [CrossRef]

102. El Zaoui, I.; Bucher, M.; Rimoldi, D.; Nicolas, M.; Kaya, G.; Pescini Gobert, R.; Bedoni, N.; Schalenbourg, A.; Sakina, E.; Zografos, L.; et al. Conjunctival Melanoma Targeted Therapy: MAPK and PI3K/mTOR Pathways Inhibition. Investig. Ophthalmol. Vis. Sci. 2019, 60, 2764-2772. [CrossRef] 
103. Pinto Torres, S.; André, T.; Gouveia, E.; Costa, L.; Passos, M.J. Systemic Treatment of Metastatic Conjunctival Melanoma. Case Rep. Oncol. Med. 2017, 2017, 4623964. [PubMed]

104. Maleka, A.; Åström, G.; Byström, P.; Ullenhag, G.J. A case report of a patient with metastatic ocular melanoma who experienced a response to treatment with the BRAF inhibitor vemurafenib. BMC Cancer 2016, 16, 634. [CrossRef] [PubMed]

105. Weber, J.L.; Smalley, K.S.; Sondak, V.K.; Gibney, G.T. Conjunctival melanomas harbor BRAF and NRAS mutations-Letter. Clin. Cancer Res. 2013, 19, 6329-6330. [CrossRef] [PubMed]

106. Dagi Glass, L.R.; Lawrence, D.P.; Jakobiec, F.A.; Freitag, S.K. Conjunctival Melanoma Responsive to Combined Systemic BRAF/MEK Inhibitors. Ophthalmic Plast. Reconstr. Surg. 2017, 33, e114-e116. [CrossRef] [PubMed]

107. Pahlitzsch, M.B.E.; Mai, C. Conjunctival Melanoma and BRAF Inhibitor Therapy. J. Clin. Exp. Ophthalmol. 2014, 5, 322. [CrossRef]

108. Robert, C.; Karaszewska, B.; Schachter, J.; Rutkowski, P.; Mackiewicz, A.; Stroiakovski, D.; Lichinitser, M.; Dummer, R.; Grange, F.; Mortier, L.; et al. Improved Overall Survival in Melanoma with Combined Dabrafenib and Trametinib. N. Engl. J. Med. 2014, 372, 30-39. [CrossRef]

109. Flaherty, K.T.; Infante, J.R.; Daud, A.; Gonzalez, R.; Kefford, R.F.; Sosman, J.; Hamid, O.; Schuchter, L.; Cebon, J.; Ibrahim, N.; et al. Combined BRAF and MEK Inhibition in Melanoma with BRAF V600 Mutations. N. Engl. J. Med. 2012, 367, 1694-1703. [CrossRef]

110. Rossi, E.; Maiorano, B.A.; Pagliara, M.M.; Sammarco, M.G.; Dosa, T.; Martini, M.; Rindi, G.; Bria, E.; Blasi, M.A.; Tortora, G.; et al. Dabrafenib and Trametinib in BRAF Mutant Metastatic Conjunctival Melanoma. Front. Oncol. 2019, 9, 232. [CrossRef]

111. Griewank, K.G.; Westekemper, H.; Schilling, B.; Livingstone, E.; Schimming, T.; Sucker, A.; Hillen, U.; Steuhl, K.-P.; Zimmer, L.; Schadendorf, D. Conjunctival Melanomas Harbor BRAF and NRAS Mutations-Response. Clin. Cancer Res. 2013, 19, 6331-6332. [CrossRef]

112. Dummer, R.; Ascierto, P.A.; Gogas, H.J.; Arance, A.; Mandala, M.; Liszkay, G.; Garbe, C.; Schadendorf, D.; Krajsova, I.; Gutzmer, R.; et al. Encorafenib plus binimetinib versus vemurafenib or encorafenib in patients with BRAF-mutant melanoma (COLUMBUS): A multicentre, open-label, randomised phase 3 trial. Lancet Oncol. 2018, 19, 603-615. [CrossRef]

113. Li, Y.; Shang, Q.; Li, P.; Cao, J.; Zhu, L.; Jager, M.J.; Fan, X.; Ge, S.; Jia, R. Characterization of a conjunctival melanoma cell line CM-AS16, newly-established from a metastatic Han Chinese patient. Exp. Eye Res. 2018, 173, 51-63. [CrossRef] [PubMed]

114. Gopal, Y.N.; Deng, W.; Woodman, S.E.; Komurov, K.; Ram, P.; Smith, P.D.; Davies, M.A. Basal and treatment-induced activation of AKT mediates resistance to cell death by AZD6244 (ARRY-142886) in Braf-mutant human cutaneous melanoma cells. Cancer Res. 2010, 70, 8736-8747. [CrossRef] [PubMed]

115. Rodon, J.; Pérez-Fidalgo, A.; Krop, I.E.; Burris, H.; Guerrero-Zotano, A.; Britten, C.D.; Becerra, C.; Schellens, J.; Richards, D.A.; Schuler, M.; et al. Phase $1 / 1 \mathrm{~b}$ dose escalation and expansion study of BEZ235, a dual PI3K/mTOR inhibitor, in patients with advanced solid tumors including patients with advanced breast cancer. Cancer Chemother. Pharmacol. 2018, 82, 285-298. [CrossRef]

116. Choo, E.F.; Ng, C.M.; Berry, L.; Belvin, M.; Lewin-Koh, N.; Merchant, M.; Salphati, L. PK-PD modeling of combination efficacy effect from administration of the MEK inhibitor GDC-0973 and PI3K inhibitor GDC-0941 in A2058 xenografts. Cancer Chemother. Pharmacol. 2013, 71, 133-143. [CrossRef] [PubMed]

117. Ciołczyk-Wierzbicka, D.; Gil, D.; Zarzycka, M.; Laidler, P. mTOR inhibitor everolimus reduces invasiveness of melanoma cells. Hum. Cell 2020, 33, 88-97. [CrossRef]

118. Carvajal, R.D.; Antonescu, C.R.; Wolchok, J.D.; Chapman, P.B.; Roman, R.-A.; Teitcher, J.; Panageas, K.S.; Busam, K.J.; Chmielowski, B.; Lutzky, J.; et al. KIT as a therapeutic target in metastatic melanoma. JAMA 2011, 305, 2327-2334. [CrossRef]

119. Guo, J.; Si, L.; Kong, Y.; Flaherty, K.T.; Xu, X.; Zhu, Y.; Corless, C.L.; Li, L.; Li, H.; Sheng, X.; et al. Phase II, open-label, single-arm trial of imatinib mesylate in patients with metastatic melanoma harboring c-Kit mutation or amplification. J. Clin. Oncol. 2011, 29, 2904-2909. [CrossRef]

120. Hodi, F.S.; Corless, C.L.; Giobbie-Hurder, A.; Fletcher, J.A.; Zhu, M.; Marino-Enriquez, A.; Friedlander, P.; Gonzalez, R.; Weber, J.S.; Gajewski, T.F.; et al. Imatinib for melanomas harboring mutationally activated or amplified KIT arising on mucosal, acral, and chronically sun-damaged skin. J. Clin. Oncol. 2013, 31, 3182-3190. [CrossRef]

121. Schuler, M.H.; Ascierto, P.A.; Vos, F.Y.F.L.D.; Postow, M.A.; Herpen, C.M.L.-V.; Carlino, M.S.; Sosman, J.A.; Berking, C.; Long, G.V.; Weise, A.; et al. Phase 1b/2 trial of ribociclib+binimetinib in metastatic NRAS-mutant melanoma: Safety, efficacy, and recommended phase 2 dose (RP2D). J. Clin. Oncol. 2017, 35, 9519. [CrossRef]

122. Sullivan, R.J.; Infante, J.R.; Janku, F.; Wong, D.J.L.; Sosman, J.A.; Keedy, V.; Patel, M.R.; Shapiro, G.I.; Mier, J.W.; Tolcher, A.W.; et al. First-in-Class ERK1/2 Inhibitor Ulixertinib (BVD-523) in Patients with MAPK Mutant Advanced Solid Tumors: Results of a Phase I Dose-Escalation and Expansion Study. Cancer Discov. 2018, 8, 184-195. [CrossRef]

123. Robert, C.; Thomas, L.; Bondarenko, I.; O’Day, S.; Weber, J.; Garbe, C.; Lebbe, C.; Baurain, J.F.; Testori, A.; Grob, J.J.; et al. Ipilimumab plus dacarbazine for previously untreated metastatic melanoma. N. Engl. J. Med. 2011, 364, 2517-2526. [CrossRef] [PubMed]

124. Hodi, F.S.; O'Day, S.J.; McDermott, D.F.; Weber, R.W.; Sosman, J.A.; Haanen, J.B.; Gonzalez, R.; Robert, C.; Schadendorf, D.; Hassel, J.C.; et al. Improved Survival with Ipilimumab in Patients with Metastatic Melanoma. N. Engl. J. Med. 2010, 363, 711-723. [CrossRef]

125. Larkin, J.; Chiarion-Sileni, V.; Gonzalez, R.; Grob, J.J.; Cowey, C.L.; Lao, C.D.; Schadendorf, D.; Dummer, R.; Smylie, M.; Rutkowski, P.; et al. Combined Nivolumab and Ipilimumab or Monotherapy in Untreated Melanoma. N. Engl. J. Med. 2015, 373, 23-34. [CrossRef] [PubMed] 
126. Sagiv, O.; Thakar, S.D.; Kandl, T.J.; Ford, J.; Sniegowski, M.C.; Hwu, W.J.; Esmaeli, B. Immunotherapy With Programmed Cell Death 1 Inhibitors for 5 Patients With Conjunctival Melanoma. JAMA Ophthalmol. 2018, 136, 1236-1241. [CrossRef] [PubMed]

127. Chaves, L.J.; Huth, B.; Augsburger, J.J.; Correa, Z.M. Eye-Sparing Treatment for Diffuse Invasive Conjunctival Melanoma. Ocul. Oncol. Pathol. 2018, 4, 261-266. [CrossRef]

128. Finger, P.T.; Pavlick, A.C. Checkpoint inhibition immunotherapy for advanced local and systemic conjunctival melanoma: A clinical case series. J. Immunother. Cancer 2019, 7, 83. [CrossRef]

129. Robert, C.; Long, G.V.; Brady, B.; Dutriaux, C.; Maio, M.; Mortier, L.; Hassel, J.C.; Rutkowski, P.; McNeil, C.; Kalinka-Warzocha, E.; et al. Nivolumab in Previously Untreated Melanoma without BRAF Mutation. N. Engl. J. Med. 2014, 372, 320-330. [CrossRef]

130. Robert, C.; Schachter, J.; Long, G.V.; Arance, A.; Grob, J.J.; Mortier, L.; Daud, A.; Carlino, M.S.; McNeil, C.; Lotem, M.; et al. Pembrolizumab versus Ipilimumab in Advanced Melanoma. N. Engl. J. Med. 2015, 372, 2521-2532. [CrossRef]

131. Kini, A.; Fu, R.; Compton, C.; Miller, D.M.; Ramasubramanian, A. Pembrolizumab for Recurrent Conjunctival Melanoma. JAMA Ophthalmol. 2017, 135, 891-892. [CrossRef]

132. Fedorenko, I.V.; Gibney, G.T.; Sondak, V.K.; Smalley, K.S. Beyond BRAF: Where next for melanoma therapy? Br. J. Cancer 2015, 112, 217-226. [CrossRef]

133. Green, D.R.; Ferguson, T.; Zitvogel, L.; Kroemer, G. Immunogenic and tolerogenic cell death. Nat. Rev. Immunol. 2009, 9, 353-363. [CrossRef] [PubMed]

134. Matzinger, P. The danger model: A renewed sense of self. Science 2002, 296, 301-305. [CrossRef] [PubMed]

135. Sharma, P.; Allison, J.P. Immune checkpoint targeting in cancer therapy: Toward combination strategies with curative potential. Cell 2015, 161, 205-214. [CrossRef] [PubMed]

136. Dong, Y.; Sun, Q.; Zhang, X. PD-1 and its ligands are important immune checkpoints in cancer. Oncotarget 2017, 8, $2171-2186$. [CrossRef] [PubMed]

137. Rowshanravan, B.; Halliday, N.; Sansom, D.M. CTLA-4: A moving target in immunotherapy. Blood 2018, 131, 58-67. [CrossRef]

138. Schwartz, R.H. Costimulation of T lymphocytes: The role of CD28, CTLA-4, and B7/BB1 in interleukin-2 production and immunotherapy. Cell 1992, 71, 1065-1068. [CrossRef]

139. Hathcock, K.S.; Laszlo, G.; Dickler, H.B.; Bradshaw, J.; Linsley, P.; Hodes, R.J. Identification of an alternative CTLA-4 ligand costimulatory for T cell activation. Science 1993, 262, 905-907. [CrossRef]

140. Boutros, C.; Tarhini, A.; Routier, E.; Lambotte, O.; Ladurie, F.L.; Carbonnel, F.; Izzeddine, H.; Marabelle, A.; Champiat, S.; Berdelou, A.; et al. Safety profiles of anti-CTLA-4 and anti-PD-1 antibodies alone and in combination. Nat. Rev. Clin. Oncol. 2016, 13, 473-486. [CrossRef]

141. Mora, J.R.; von Andrian, U.H. T-cell homing specificity and plasticity: New concepts and future challenges. Trends Immunol. 2006, 27, 235-243. [CrossRef]

142. Keir, M.E.; Butte, M.J.; Freeman, G.J.; Sharpe, A.H. PD-1 and its ligands in tolerance and immunity. Annu. Rev. Immunol. 2008, 26, 677-704. [CrossRef]

143. Ott, P.A.; Hodi, F.S.; Robert, C. CTLA-4 and PD-1/PD-L1 blockade: New immunotherapeutic modalities with durable clinical benefit in melanoma patients. Clin. Cancer Res. 2013, 19, 5300-5309. [CrossRef] [PubMed]

144. Postow, M.A.; Chesney, J.; Pavlick, A.C.; Robert, C.; Grossmann, K.; McDermott, D.; Linette, G.P.; Meyer, N.; Giguere, J.K.; Agarwala, S.S.; et al. Nivolumab and ipilimumab versus ipilimumab in untreated melanoma. N. Engl. J. Med. 2015, 372, $2006-2017$. [CrossRef] [PubMed]

145. Robert, C.; Ribas, A.; Wolchok, J.D.; Hodi, F.S.; Hamid, O.; Kefford, R.; Weber, J.S.; Joshua, A.M.; Hwu, W.J.; Gangadhar, T.C.; et al. Anti-programmed-death-receptor-1 treatment with pembrolizumab in ipilimumab-refractory advanced melanoma: A randomised dose-comparison cohort of a phase 1 trial. Lancet 2014, 384, 1109-1117. [CrossRef]

146. Larkin, J.; Hodi, F.S.; Wolchok, J.D. Combined Nivolumab and Ipilimumab or Monotherapy in Untreated Melanoma. N. Engl. J. Med. 2015, 373, 1270-1271. [CrossRef] [PubMed]

147. Cybulska-Stopa, B.; Rogala, P.; Czarnecka, A.M.; Lugowska, I.; Teterycz, P.; Galus, L.; Rajczykowski, M.; Dawidowska, A.; Piejko, K.; Suwinski, R.; et al. Efficacy of ipilimumab after anti-PD-1 therapy in sequential treatment of metastatic melanoma patients-Real world evidence. Adv. Med. Sci. 2020, 65, 316-323. [CrossRef]

148. Tarhini, A. Immune-mediated adverse events associated with ipilimumab ctla-4 blockade therapy: The underlying mechanisms and clinical management. Scientifica 2013, 2013, 857519. [CrossRef]

149. Papavasileiou, E.; Prasad, S.; Freitag, S.K.; Sobrin, L.; Lobo, A.M. Ipilimumab-induced Ocular and Orbital Inflammation-A Case Series and Review of the Literature. Ocul. Immunol. Inflamm. 2016, 24, 140-146. [CrossRef]

150. Wang, W.; Lam, W.C.; Chen, L. Recurrent grade 4 panuveitis with serous retinal detachment related to nivolumab treatment in a patient with metastatic renal cell carcinoma. Cancer Immunol. Immunother. 2019, 68, 85-95. [CrossRef]

151. Dillman, R.O.; Nistor, G.I.; Cornforth, A.N. Dendritic cell vaccines for melanoma: Past, present and future. Melanoma Manag. 2016, 3, 273-289. [CrossRef]

152. O'Neill, D.W.; Adams, S.; Bhardwaj, N. Manipulating dendritic cell biology for the active immunotherapy of cancer. Blood 2004, 104, 2235-2246. [CrossRef]

153. van Beek, J.J.; Wimmers, F.; Hato, S.V.; de Vries, I.J.; Skold, A.E. Dendritic cell cross talk with innate and innate-like effector cells in antitumor immunity: Implications for DC vaccination. Crit. Rev. Immunol. 2014, 34, 517-536. [CrossRef] [PubMed]

154. Palucka, K.; Banchereau, J. Cancer immunotherapy via dendritic cells. Nat. Rev. Cancer 2012, 12, 265-277. [CrossRef] [PubMed] 
155. Schadendorf, D.; Ugurel, S.; Schuler-Thurner, B.; Nestle, F.O.; Enk, A.; Brocker, E.B.; Grabbe, S.; Rittgen, W.; Edler, L.; Sucker, A.; et al. Dacarbazine (DTIC) versus vaccination with autologous peptide-pulsed dendritic cells (DC) in first-line treatment of patients with metastatic melanoma: A randomized phase III trial of the DC study group of the DeCOG. Ann. Oncol. 2006, 17, 563-570. [CrossRef]

156. Hsu, F.J.; Benike, C.; Fagnoni, F.; Liles, T.M.; Czerwinski, D.; Taidi, B.; Engleman, E.G.; Levy, R. Vaccination of patients with B-cell lymphoma using autologous antigen-pulsed dendritic cells. Nat. Med. 1996, 2, 52-58. [CrossRef] [PubMed]

157. Cheever, M.A.; Higano, C.S. PROVENGE (Sipuleucel-T) in prostate cancer: The first FDA-approved therapeutic cancer vaccine. Clin. Cancer Res. 2011, 17, 3520-3526. [CrossRef] [PubMed]

158. Bol, K.F.; Schreibelt, G.; Gerritsen, W.R.; de Vries, I.J.; Figdor, C.G. Dendritic Cell-Based Immunotherapy: State of the Art and Beyond. Clin. Cancer Res. 2016, 22, 1897-1906. [CrossRef] [PubMed]

159. Constantino, J.; Gomes, C.; Falcão, A.; Neves, B.M.; Cruz, M.T. Dendritic cell-based immunotherapy: A basic review and recent advances. Immunol. Res. 2017, 65, 798-810. [CrossRef]

160. López, M.N.; Pereda, C.; Segal, G.; Muñoz, L.; Aguilera, R.; González, F.E.; Escobar, A.; Ginesta, A.; Reyes, D.; González, R.; et al. Prolonged survival of dendritic cell-vaccinated melanoma patients correlates with tumor-specific delayed type IV hypersensitivity response and reduction of tumor growth factor beta-expressing T cells. J. Clin. Oncol. 2009, 27, 945-952. [CrossRef]

161. Stritt, S.; Koltowska, K.; Makinen, T. Homeostatic maintenance of the lymphatic vasculature. Trends Mol. Med. 2021, 27, 955-970. [CrossRef]

162. Gonzalez-Loyola, A.; Petrova, T.V. Development and aging of the lymphatic vascular system. Adv. Drug Deliv. Rev. 2021, 169, 63-78. [CrossRef]

163. Aspelund, A.; Robciuc, M.R.; Karaman, S.; Makinen, T.; Alitalo, K. Lymphatic System in Cardiovascular Medicine. Circ. Res. 2016, 118, 515-530. [CrossRef] [PubMed]

164. Baluk, P.; Fuxe, J.; Hashizume, H.; Romano, T.; Lashnits, E.; Butz, S.; Vestweber, D.; Corada, M.; Molendini, C.; Dejana, E.; et al. Functionally specialized junctions between endothelial cells of lymphatic vessels. J. Exp. Med. 2007, 204, 2349-2362. [CrossRef] [PubMed]

165. Bromley, S.K.; Thomas, S.Y.; Luster, A.D. Chemokine receptor CCR7 guides T cell exit from peripheral tissues and entry into afferent lymphatics. Nat. Immunol. 2005, 6, 895-901. [CrossRef] [PubMed]

166. Bromley, S.K.; Yan, S.; Tomura, M.; Kanagawa, O.; Luster, A.D. Recirculating memory T cells are a unique subset of CD4+ T cells with a distinct phenotype and migratory pattern. J. Immunol. 2013, 190, 970-976. [CrossRef] [PubMed]

167. Scheinecker, C.; McHugh, R.; Shevach, E.M.; Germain, R.N. Constitutive presentation of a natural tissue autoantigen exclusively by dendritic cells in the draining lymph node. J. Exp. Med. 2002, 196, 1079-1090. [CrossRef]

168. Worbs, T.; Bode, U.; Yan, S.; Hoffmann, M.W.; Hintzen, G.; Bernhardt, G.; Forster, R.; Pabst, O. Oral tolerance originates in the intestinal immune system and relies on antigen carriage by dendritic cells. J. Exp. Med. 2006, 203, 519-527. [CrossRef]

169. Forster, R.; Braun, A.; Worbs, T. Lymph node homing of T cells and dendritic cells via afferent lymphatics. Trends Immunol. 2012, 33, 271-280. [CrossRef]

170. Ohl, L.; Mohaupt, M.; Czeloth, N.; Hintzen, G.; Kiafard, Z.; Zwirner, J.; Blankenstein, T.; Henning, G.; Forster, R. CCR7 governs skin dendritic cell migration under inflammatory and steady-state conditions. Immunity 2004, 21, 279-288. [CrossRef]

171. Forster, R.; Davalos-Misslitz, A.C.; Rot, A. CCR7 and its ligands: Balancing immunity and tolerance. Nat. Rev. Immunol. 2008, 8, 362-371. [CrossRef]

172. Vaahtomeri, K.; Brown, M.; Hauschild, R.; De Vries, I.; Leithner, A.F.; Mehling, M.; Kaufmann, W.A.; Sixt, M. Locally Triggered Release of the Chemokine CCL21 Promotes Dendritic Cell Transmigration across Lymphatic Endothelia. Cell Rep. 2017, 19, 902-909. [CrossRef]

173. Vaahtomeri, K.; Karaman, S.; Makinen, T.; Alitalo, K. Lymphangiogenesis guidance by paracrine and pericellular factors. Genes Dev. 2017, 31, 1615-1634. [CrossRef] [PubMed]

174. Hagerling, R.; Pollmann, C.; Andreas, M.; Schmidt, C.; Nurmi, H.; Adams, R.H.; Alitalo, K.; Andresen, V.; Schulte-Merker, S.; Kiefer, F. A novel multistep mechanism for initial lymphangiogenesis in mouse embryos based on ultramicroscopy. EMBO J. 2013, 32, 629-644. [CrossRef] [PubMed]

175. Karkkainen, M.J.; Haiko, P.; Sainio, K.; Partanen, J.; Taipale, J.; Petrova, T.V.; Jeltsch, M.; Jackson, D.G.; Talikka, M.; Rauvala, H.; et al. Vascular endothelial growth factor $\mathrm{C}$ is required for sprouting of the first lymphatic vessels from embryonic veins. Nat. Immunol. 2004, 5, 74-80. [CrossRef] [PubMed]

176. Alitalo, K. The lymphatic vasculature in disease. Nat. Med. 2011, 17, 1371-1380. [CrossRef] [PubMed]

177. Kahn, M.L.; Guillermo, O. Lymphangiogenesis-Methods and Protocols; Part of Springer Nature; Springer Science + Business Media, LLC: Berlin/Heidelberg, Germany, 2018.

178. Oliver, G.; Kipnis, J.; Randolph, G.J.; Harvey, N.L. The Lymphatic Vasculature in the 21(st) Century: Novel Functional Roles in Homeostasis and Disease. Cell 2020, 182, 270-296. [CrossRef] [PubMed]

179. Karaman, S.; Detmar, M. Mechanisms of lymphatic metastasis. J. Clin. Investig. 2014, 124, 922-928. [CrossRef] [PubMed]

180. Bohmer, R.; Neuhaus, B.; Buhren, S.; Zhang, D.; Stehling, M.; Bock, B.; Kiefer, F. Regulation of developmental lymphangiogenesis by Syk(+) leukocytes. Dev. Cell 2010, 18, 437-449. [CrossRef] 
181. Rapanotti, M.C.; Cugini, E.; Nuccetelli, M.; Terrinoni, A.; Di Raimondo, C.; Lombardo, P.; Costanza, G.; Cosio, T.; Rossi, P.; Orlandi, A.; et al. MCAM/MUC18/CD146 as a Multifaceted Warning Marker of Melanoma Progression in Liquid Biopsy. Int. J. Mol. Sci. 2021, 22, 12416. [CrossRef]

182. Ma, Q.; Dieterich, L.C.; Detmar, M. Multiple roles of lymphatic vessels in tumor progression. Curr. Opin. Immunol. 2018, 53, 7-12. [CrossRef]

183. Alitalo, A.; Detmar, M. Interaction of tumor cells and lymphatic vessels in cancer progression. Oncogene 2012, 31, 4499-4508. [CrossRef]

184. Fankhauser, M.; Broggi, M.A.S.; Potin, L.; Bordry, N.; Jeanbart, L.; Lund, A.W.; Da Costa, E.; Hauert, S.; Rincon-Restrepo, M.; Tremblay, C.; et al. Tumor lymphangiogenesis promotes T cell infiltration and potentiates immunotherapy in melanoma. Sci. Transl. Med. 2017, 9, eaal4712. [CrossRef] [PubMed]

185. Vaahtomeri, K.; Alitalo, K. Lymphatic Vessels in Tumor Dissemination versus Immunotherapy. Cancer Res. 2020, 80, 3463-3465. [CrossRef] [PubMed]

186. Bock, F.; Maruyama, K.; Regenfuss, B.; Hos, D.; Steven, P.; Heindl, L.M.; Cursiefen, C. Novel anti(lymph)angiogenic treatment strategies for corneal and ocular surface diseases. Prog. Retin. Eye Res. 2013, 34, 89-124. [CrossRef] [PubMed]

187. Gong, P.; Yu, D.Y.; Wang, Q.; Yu, P.K.; Karnowski, K.; Heisler, M.; Francke, A.; An, D.; Sarunic, M.V.; Sampson, D.D. Label-free volumetric imaging of conjunctival collecting lymphatics ex vivo by optical coherence tomography lymphangiography. $J$. Biophotonics 2018, 11, e201800070. [CrossRef] [PubMed]

188. Wu, Y.; Seong, Y.J.; Li, K.; Choi, D.; Park, E.; Daghlian, G.H.; Jung, E.; Bui, K.; Zhao, L.; Madhavan, S.; et al. Organogenesis and distribution of the ocular lymphatic vessels in the anterior eye. JCI Insight 2020, 5, e135121. [CrossRef]

189. Schlereth, S.L.; Neuser, B.; Herwig, M.C.; Müller, A.M.; Koch, K.R.; Reitsamer, H.A.; Schrödl, F.; Cursiefen, C.; Heindl, L.M. Absence of lymphatic vessels in the developing human sclera. Exp. Eye Res. 2014, 125, 203-209. [CrossRef] [PubMed]

190. Schlereth, S.L.; Karlstetter, M.; Hos, D.; Matthaei, M.; Cursiefen, C.; Heindl, L.M. Detection of Pro- and Antiangiogenic Factors in the Human Sclera. Curr. Eye Res. 2019, 44, 172-184. [CrossRef]

191. Schlereth, S.L.; Iden, S.; Mescher, M.; Ksander, B.R.; Bosch, J.J.; Cursiefen, C.; Heindl, L.M. A Novel Model of Metastatic Conjunctival Melanoma in Immune-Competent Mice. Investig. Ophthalmol. Vis. Sci. 2015, 56, 5965-5973. [CrossRef]

192. Heindl, L.M.; Hofmann-Rummelt, C.; Adler, W.; Bosch, J.J.; Holbach, L.M.; Naumann, G.O.; Kruse, F.E.; Cursiefen, C. Tumorassociated lymphangiogenesis in the development of conjunctival melanoma. Investig. Ophthalmol. Vis. Sci. 2011, 52, 7074-7083. [CrossRef]

193. Zimmermann, P.; Dietrich, T.; Bock, F.; Horn, F.K.; Hofmann-Rummelt, C.; Kruse, F.E.; Cursiefen, C. Tumour-associated lymphangiogenesis in conjunctival malignant melanoma. Br. J. Ophthalmol. 2009, 93, 1529-1534. [CrossRef]

194. Heindl, L.M.; Hofmann-Rummelt, C.; Adler, W.; Bosch, J.J.; Holbach, L.M.; Naumann, G.O.; Kruse, F.E.; Cursiefen, C. Prognostic significance of tumor-associated lymphangiogenesis in malignant melanomas of the conjunctiva. Ophthalmology 2011, 118, 2351-2360. [CrossRef] [PubMed]

195. Briceno, C.A.; Elner, V.M.; Demirci, H. Lymphangiogenic and Chemotactic Factors in Conjunctival Melanoma. Ophthalmic Plast. Reconstr. Surg. 2016, 32, 428-433. [CrossRef] [PubMed]

196. Mohos, A.; Sebestyen, T.; Liszkay, G.; Plotar, V.; Horvath, S.; Gaudi, I.; Ladanyi, A. Immune cell profile of sentinel lymph nodes in patients with malignant melanoma-FOXP3 + cell density in cases with positive sentinel node status is associated with unfavorable clinical outcome. J. Transl. Med. 2013, 11, 43. [CrossRef] [PubMed]

197. Hart, D.N. Dendritic cells: Unique leukocyte populations which control the primary immune response. Blood 1997, 90, 3245-3287. [CrossRef]

198. Shortman, K.; Caux, C. Dendritic cell development: Multiple pathways to nature's adjuvants. Stem Cells 1997, 15, 409-419. [CrossRef]

199. Macri, C.; Pang, E.S.; Patton, T.; O’Keeffe, M. Dendritic cell subsets. Semin Cell Dev. Biol 2018, 84, 11-21. [CrossRef]

200. Merad, M.; Sathe, P.; Helft, J.; Miller, J.; Mortha, A. The dendritic cell lineage: Ontogeny and function of dendritic cells and their subsets in the steady state and the inflamed setting. Annu. Rev. Immunol. 2013, 31, 563-604. [CrossRef]

201. Shortman, K.; Heath, W.R. The CD8+ dendritic cell subset. Immunol. Rev. 2010, 234, 18-31. [CrossRef]

202. Swiecki, M.; Colonna, M. The multifaceted biology of plasmacytoid dendritic cells. Nat. Rev. Immunol. 2015, 15, 471-485. [CrossRef]

203. Veglia, F.; Gabrilovich, D.I. Dendritic cells in cancer: The role revisited. Curr. Opin. Immunol. 2017, 45, 43-51. [CrossRef]

204. Sichien, D.; Lambrecht, B.N.; Guilliams, M.; Scott, C.L. Development of conventional dendritic cells: From common bone marrow progenitors to multiple subsets in peripheral tissues. Mucosal Immunol. 2017, 10, 831-844. [CrossRef] [PubMed]

205. Luber, C.A.; Cox, J.; Lauterbach, H.; Fancke, B.; Selbach, M.; Tschopp, J.; Akira, S.; Wiegand, M.; Hochrein, H.; O’Keeffe, M.; et al. Quantitative proteomics reveals subset-specific viral recognition in dendritic cells. Immunity 2010, 32, 279-289. [CrossRef] [PubMed]

206. Edwards, A.D.; Diebold, S.S.; Slack, E.M.C.; Tomizawa, H.; Hemmi, H.; Kaisho, T.; Akira, S.; Sousa, C.R.E. Toll-like receptor expression in murine DC subsets: Lack of TLR7 expression by CD8 $\alpha+$ DC correlates with unresponsiveness to imidazoquinolines. Eur. J. Immunol. 2003, 33, 827-833. [CrossRef] [PubMed]

207. Hochrein, H.; Shortman, K.; Vremec, D.; Scott, B.; Hertzog, P.; O’Keeffe, M. Differential Production of IL-12, IFN- $\alpha$, and IFN- $\gamma$ by Mouse Dendritic Cell Subsets. J. Immunol. 2001, 166, 5448-5455. [CrossRef] [PubMed] 
208. Rizzitelli, A.; Hawkins, E.; Todd, H.; Hodgkin, P.D.; Shortman, K. The proliferative response of CD4 T cells to steady-state CD8+ dendritic cells is restricted by post-activation death. Int. Immunol. 2006, 18, 415-423. [CrossRef]

209. den Haan, J.M.; Lehar, S.M.; Bevan, M.J. CD8+ but not CD8- dendritic cells cross-prime cytotoxic T cells in vivo. J. Exp. Med. 2000, 192, 1685-1696. [CrossRef]

210. Sancho, D.; Joffre, O.P.; Keller, A.M.; Rogers, N.C.; Martínez, D.; Hernanz-Falcón, P.; Rosewell, I.; Sousa, C.R.E. Identification of a dendritic cell receptor that couples sensing of necrosis to immunity. Nature 2009, 458, 899-903. [CrossRef]

211. Caminschi, I.; Proietto, A.I.; Ahmet, F.; Kitsoulis, S.; Shin Teh, J.; Lo, J.C.; Rizzitelli, A.; Wu, L.; Vremec, D.; van Dommelen, S.L.; et al. The dendritic cell subtype-restricted C-type lectin Clec9A is a target for vaccine enhancement. Blood 2008, 112, 3264-3273. [CrossRef]

212. Greyer, M.; Whitney, P.G.; Stock, A.T.; Davey, G.M.; Tebartz, C.; Bachem, A.; Mintern, J.D.; Strugnell, R.A.; Turner, S.J.; Gebhardt, T.; et al. T Cell Help Amplifies Innate Signals in CD8(+) DCs for Optimal CD8(+) T Cell Priming. Cell Rep. 2016, 14, 586-597. [CrossRef]

213. Roberts, E.W.; Broz, M.L.; Binnewies, M.; Headley, M.B.; Nelson, A.E.; Wolf, D.M.; Kaisho, T.; Bogunovic, D.; Bhardwaj, N.; Krummel, M.F. Critical Role for CD103(+)/CD141(+) Dendritic Cells Bearing CCR7 for Tumor Antigen Trafficking and Priming of T Cell Immunity in Melanoma. Cancer Cell 2016, 30, 324-336. [CrossRef]

214. Salmon, H.; Idoyaga, J.; Rahman, A.; Leboeuf, M.; Remark, R.; Jordan, S.; Casanova-Acebes, M.; Khudoynazarova, M.; Agudo, J.; Tung, N.; et al. Expansion and Activation of CD103(+) Dendritic Cell Progenitors at the Tumor Site Enhances Tumor Responses to Therapeutic PD-L1 and BRAF Inhibition. Immunity 2016, 44, 924-938. [CrossRef] [PubMed]

215. Prokopi, A.; Tripp, C.H.; Tummers, B.; Hornsteiner, F.; Spoeck, S.; Crawford, J.C.; Clements, D.R.; Efremova, M.; Hutter, K.; Bellmann, L.; et al. Skin dendritic cells in melanoma are key for successful checkpoint blockade therapy. J. Immunother. Cancer 2021, 9, e000832. [CrossRef] [PubMed]

216. Spranger, S.; Bao, R.; Gajewski, T.F. Melanoma-intrinsic $\beta$-catenin signalling prevents anti-tumour immunity. Nature 2015, 523, 231-235. [CrossRef] [PubMed]

217. Broz, M.L.; Binnewies, M.; Boldajipour, B.; Nelson, A.E.; Pollack, J.L.; Erle, D.J.; Barczak, A.; Rosenblum, M.D.; Daud, A.; Barber, D.L.; et al. Dissecting the Tumor Myeloid Compartment Reveals Rare Activating Antigen-Presenting Cells Critical for T Cell Immunity. Cancer Cell 2014, 26, 938. [CrossRef]

218. Ruffell, B.; Chang-Strachan, D.; Chan, V.; Rosenbusch, A.; Ho, C.M.; Pryer, N.; Daniel, D.; Hwang, E.S.; Rugo, H.S.; Coussens, L.M. Macrophage IL-10 blocks CD8+ T cell-dependent responses to chemotherapy by suppressing IL-12 expression in intratumoral dendritic cells. Cancer Cell 2014, 26, 623-637. [CrossRef]

219. Hildner, K.; Edelson, B.T.; Purtha, W.E.; Diamond, M.; Matsushita, H.; Kohyama, M.; Calderon, B.; Schraml, B.U.; Unanue, E.R.; Diamond, M.S.; et al. Batf3 deficiency reveals a critical role for CD8alpha+ dendritic cells in cytotoxic T cell immunity. Science 2008, 322, 1097-1100. [CrossRef]

220. Rhodes, J.W.; Tong, O.; Harman, A.N.; Turville, S.G. Human Dendritic Cell Subsets, Ontogeny, and Impact on HIV Infection. Front. Immunol. 2019, 10, 1088. [CrossRef]

221. Jongbloed, S.L.; Kassianos, A.J.; McDonald, K.J.; Clark, G.J.; Ju, X.; Angel, C.E.; Chen, C.J.; Dunbar, P.R.; Wadley, R.B.; Jeet, V.; et al. Human CD141+ (BDCA-3)+ dendritic cells (DCs) represent a unique myeloid DC subset that cross-presents necrotic cell antigens. J. Exp. Med. 2010, 207, 1247-1260. [CrossRef]

222. Lauterbach, H.; Bathke, B.; Gilles, S.; Traidl-Hoffmann, C.; Luber, C.A.; Fejer, G.; Freudenberg, M.A.; Davey, G.M.; Vremec, D.; Kallies, A.; et al. Mouse CD $8 \alpha+$ DCs and human BDCA3+ DCs are major producers of IFN- $\lambda$ in response to poly IC. J. Exp. Med. 2010, 207, 2703-2717. [CrossRef]

223. O'Keeffe, M.; Mok, W.H.; Radford, K.J. Human dendritic cell subsets and function in health and disease. Cell. Mol. Life Sci. 2015, 72, 4309-4325. [CrossRef]

224. Binnewies, M.; Mujal, A.M.; Pollack, J.L.; Combes, A.J.; Hardison, E.A.; Barry, K.C.; Tsui, J.; Ruhland, M.K.; Kersten, K.; Abushawish, M.A.; et al. Unleashing Type-2 Dendritic Cells to Drive Protective Antitumor CD4(+) T Cell Immunity. Cell 2019, 177, 556-571.e16. [CrossRef]

225. Proietto, A.I.; O'Keeffe, M.; Gartlan, K.; Wright, M.D.; Shortman, K.; Wu, L.; Lahoud, M.H. Differential production of inflammatory chemokines by murine dendritic cell subsets. Immunobiology 2004, 209, 163-172. [CrossRef] [PubMed]

226. Kasahara, S.; Clark, E.A. Dendritic cell-associated lectin 2 (DCAL2) defines a distinct CD8 $\alpha-$ dendritic cell subset. J. Leukoc. Biol. 2012, 91, 437-448. [CrossRef] [PubMed]

227. Lewis, K.L.; Caton, M.L.; Bogunovic, M.; Greter, M.; Grajkowska, L.T.; Ng, D.; Klinakis, A.; Charo, I.F.; Jung, S.; Gommerman, J.L.; et al. Notch2 receptor signaling controls functional differentiation of dendritic cells in the spleen and intestine. Immunity 2011, 35, 780-791. [CrossRef] [PubMed]

228. Mittag, D.; Proietto, A.I.; Loudovaris, T.; Mannering, S.I.; Vremec, D.; Shortman, K.; Wu, L.; Harrison, L.C. Human Dendritic Cell Subsets from Spleen and Blood Are Similar in Phenotype and Function but Modified by Donor Health Status. J. Immunol. 2011, 186, 6207-6217. [CrossRef]

229. Yin, X.; Yu, H.; Jin, X.; Li, J.; Guo, H.; Shi, Q.; Yin, Z.; Xu, Y.; Wang, X.; Liu, R.; et al. Human Blood CD1c ${ }^{+}$Dendritic Cells Encompass CD5 $5^{\text {high }}$ and CD5 ${ }^{\text {low }}$ Subsets That Differ Significantly in Phenotype, Gene Expression, and Functions. J. Immunol. 2017, 198, 1553-1564. [CrossRef] [PubMed] 
230. Chevolet, I.; Speeckaert, R.; Schreuer, M.; Neyns, B.; Krysko, O.; Bachert, C.; Van Gele, M.; van Geel, N.; Brochez, L. Clinical significance of plasmacytoid dendritic cells and myeloid-derived suppressor cells in melanoma. J. Transl. Med. 2015, 13, 9. [CrossRef]

231. Helft, J.; Ginhoux, F.; Bogunovic, M.; Merad, M. Origin and functional heterogeneity of non-lymphoid tissue dendritic cells in mice. Immunol. Rev. 2010, 234, 55-75. [CrossRef]

232. Bogunovic, M.; Ginhoux, F.; Helft, J.; Shang, L.; Hashimoto, D.; Greter, M.; Liu, K.; Jakubzick, C.; Ingersoll, M.A.; Leboeuf, M.; et al. Origin of the lamina propria dendritic cell network. Immunity 2009, 31, 513-525. [CrossRef]

233. Randolph, G.J.; Angeli, V.; Swartz, M.A. Dendritic-cell trafficking to lymph nodes through lymphatic vessels. Nat. Rev. Immunol. 2005, 5, 617-628. [CrossRef]

234. Merad, M.; Ginhoux, F.; Collin, M. Origin, homeostasis and function of Langerhans cells and other langerin-expressing dendritic cells. Nat. Rev. Immunol. 2008, 8, 935-947. [CrossRef]

235. Collin, M.; Milne, P. Langerhans cell origin and regulation. Curr. Opin. Hematol. 2016, 23, 28-35. [CrossRef] [PubMed]

236. Romano, E.; Cotari, J.W.; Barreira da Silva, R.; Betts, B.C.; Chung, D.J.; Avogadri, F.; Fink, M.J.; St Angelo, E.T.; Mehrara, B.; Heller, G.; et al. Human Langerhans cells use an IL-15R- $\alpha$ /IL-15/pSTAT5-dependent mechanism to break T-cell tolerance against the self-differentiation tumor antigen WT1. Blood 2012, 119, 5182-5190. [CrossRef] [PubMed]

237. Collin, M.; Bigley, V. Human dendritic cell subsets: An update. Immunology 2018, 154, 3-20. [CrossRef] [PubMed]

238. Kim, J.H.; Hu, Y.; Yongqing, T.; Kim, J.; Hughes, V.A.; Le Nours, J.; Marquez, E.A.; Purcell, A.W.; Wan, Q.; Sugita, M.; et al. CD1a on Langerhans cells controls inflammatory skin disease. Nat. Immunol. 2016, 17, 1159-1166. [CrossRef] [PubMed]

239. Omine, Y.; Hinata, N.; Yamamoto, M.; Kasahara, M.; Matsunaga, S.; Murakami, G.; Abe, S. Regional differences in the density of Langerhans cells, CD8-positive T lymphocytes and CD68-positive macrophages: A preliminary study using elderly donated cadavers. Anat. Cell Biol. 2015, 48, 177-187. [CrossRef] [PubMed]

240. Takaoka, A.; Yanai, H. Interferon signalling network in innate defence. Cell Microbiol. 2006, 8, 907-922. [CrossRef]

241. Sathe, P.; Vremec, D.; Wu, L.; Corcoran, L.; Shortman, K. Convergent differentiation: Myeloid and lymphoid pathways to murine plasmacytoid dendritic cells. Blood 2013, 121, 11-19. [CrossRef]

242. Swiecki, M.; Colonna, M. Unraveling the functions of plasmacytoid dendritic cells during viral infections, autoimmunity, and tolerance. Immunol. Rev. 2010, 234, 142-162. [CrossRef]

243. Wculek, S.K.; Cueto, F.J.; Mujal, A.M.; Melero, I.; Krummel, M.F.; Sancho, D. Dendritic cells in cancer immunology and immunotherapy. Nat. Rev. Immunol. 2020, 20, 7-24. [CrossRef]

244. Reizis, B.; Bunin, A.; Ghosh, H.S.; Lewis, K.L.; Sisirak, V. Plasmacytoid Dendritic Cells: Recent Progress and Open Questions. Annu. Rev. Immunol. 2011, 29, 163-183. [CrossRef] [PubMed]

245. van Beek, J.J.P.; Florez-Grau, G.; Gorris, M.A.J.; Mathan, T.S.M.; Schreibelt, G.; Bol, K.F.; Textor, J.; de Vries, I.J.M. Human pDCs Are Superior to cDC2s in Attracting Cytolytic Lymphocytes in Melanoma Patients Receiving DC Vaccination. Cell Rep. 2020, 30, 1027-1038.e4. [CrossRef] [PubMed]

246. Drobits, B.; Holcmann, M.; Amberg, N.; Swiecki, M.; Grundtner, R.; Hammer, M.; Colonna, M.; Sibilia, M. Imiquimod clears tumors in mice independent of adaptive immunity by converting pDCs into tumor-killing effector cells. J. Clin. Investig. 2012, 122, 575-585. [CrossRef] [PubMed]

247. Segura, E.; Amigorena, S. Inflammatory dendritic cells in mice and humans. Trends Immunol. 2013, 34, 440-445. [CrossRef]

248. Segura, E.; Touzot, M.; Bohineust, A.; Cappuccio, A.; Chiocchia, G.; Hosmalin, A.; Dalod, M.; Soumelis, V.; Amigorena, S. Human inflammatory dendritic cells induce Th17 cell differentiation. Immunity 2013, 38, 336-348. [CrossRef]

249. Ohbayashi, M.; Manzouri, B.; Flynn, T.; Toda, M.; Ikeda, Y.; Nakamura, T.; Ono, S.J. Dynamic changes in conjunctival dendritic cell numbers, anatomical position and phenotype during experimental allergic conjunctivitis. Exp. Mol. Pathol. 2007, 83, 216-223. [CrossRef]

250. Jamali, A.; Harris, D.L.; Blanco, T.; Lopez, M.J.; Hamrah, P. Resident plasmacytoid dendritic cells patrol vessels in the naïve limbus and conjunctiva. Ocul. Surf. 2020, 18, 277-285. [CrossRef]

251. Messmer, E.M.; Mackert, M.J.; Zapp, D.M.; Kampik, A. In vivo confocal microscopy of pigmented conjunctival tumors. Graefes Arch. Clin. Exp. Ophthalmol. 2006, 244, 1437-1445. [CrossRef]

252. Cinotti, E.; Singer, A.; Labeille, B.; Grivet, D.; Rubegni, P.; Douchet, C.; Cambazard, F.; Thuret, G.; Gain, P.; Perrot, J.L. Handheld In Vivo Reflectance Confocal Microscopy for the Diagnosis of Eyelid Margin and Conjunctival Tumors. JAMA Ophthalmol. 2017, 135, 845-851. [CrossRef]

253. Rodrigues, M.M.; Rowden, G.; Hackett, J.; Bakos, I. Langerhans cells in the normal conjunctiva and peripheral cornea of selected species. Investig. Ophthalmol. Vis. Sci. 1981, 21, 759-765.

254. Steuhl, K.P.; Sitz, U.; Knorr, M.; Thanos, S.; Thiel, H.J. Age-dependent distribution of Langerhans cells within human conjunctival epithelium. Ophthalmologe 1995, 92, 21-25. [PubMed]

255. Khandelwal, P.; Blanco-Mezquita, T.; Emami, P.; Lee, H.S.; Reyes, N.J.; Mathew, R.; Huang, R.; Saban, D.R. Ocular mucosal $\mathrm{CD} 11 \mathrm{~b}+$ and CD103+ mouse dendritic cells under normal conditions and in allergic immune responses. PLoS ONE 2013, 8, e64193. [CrossRef] [PubMed]

256. Schlereth, S.; Lee, H.S.; Khandelwal, P.; Saban, D.R. Blocking CCR7 at the ocular surface impairs the pathogenic contribution of dendritic cells in allergic conjunctivitis. Am. J. Pathol. 2012, 180, 2351-2360. [CrossRef] [PubMed] 
257. Gandhi, N.B.; Su, Z.; Zhang, X.; Volpe, E.A.; Pelegrino, F.S.; Rahman, S.A.; Li, D.Q.; Pflugfelder, S.C.; de Paiva, C.S. Dendritic cell-derived thrombospondin-1 is critical for the generation of the ocular surface Th17 response to desiccating stress. J. Leukoc. Biol. 2013, 94, 1293-1301. [CrossRef]

258. Logeswaran, A.; Contreras-Ruiz, L.; Masli, S. Conjunctival Goblet Cell Responses to TLR5 Engagement Promote Activation of Local Antigen-Presenting Cells. Front. Immunol. 2021, 12, 716939. [CrossRef] [PubMed]

259. Wang, Y.; Zhao, F.; Zhu, W.; Xu, J.; Zheng, T.; Sun, X. In vivo confocal microscopic evaluation of morphologic changes and dendritic cell distribution in pterygium. Am. J. Ophthalmol. 2010, 150, 650-655.e1. [CrossRef]

260. Wolf, J.; Auw-Haedrich, C.; Schlecht, A.; Boneva, S.; Mittelviefhaus, H.; Lapp, T.; Agostini, H.; Reinhard, T.; Schlunck, G.; Lange, C.A.K. Transcriptional characterization of conjunctival melanoma identifies the cellular tumor microenvironment and prognostic gene signatures. Sci. Rep. 2020, 10, 17022. [CrossRef]

261. Mitchell, D.; Chintala, S.; Dey, M. Plasmacytoid dendritic cell in immunity and cancer. J. NeuroImmunol. 2018, 322, 63-73. [CrossRef]

262. Diao, J.; Gu, H.; Tang, M.; Zhao, J.; Cattral, M.S. Tumor Dendritic Cells (DCs) Derived from Precursors of Conventional DCs Are Dispensable for Intratumor CTL Responses. J. Immunol. 2018, 201, 1306-1314. [CrossRef]

263. Tang, M.; Diao, J.; Gu, H.; Khatri, I.; Zhao, J.; Cattral, M.S. Toll-like Receptor 2 Activation Promotes Tumor Dendritic Cell Dysfunction by Regulating IL-6 and IL-10 Receptor Signaling. Cell Rep. 2015, 13, 2851-2864. [CrossRef]

264. Langlet, C.; Tamoutounour, S.; Henri, S.; Luche, H.; Ardouin, L.; Grégoire, C.; Malissen, B.; Guilliams, M. CD64 expression distinguishes monocyte-derived and conventional dendritic cells and reveals their distinct role during intramuscular immunization. $J$. Immunol. 2012, 188, 1751-1760. [CrossRef] [PubMed]

265. Ladanyi, A.; Kiss, J.; Somlai, B.; Gilde, K.; Fejos, Z.; Mohos, A.; Gaudi, I.; Timar, J. Density of DC-LAMP(+) mature dendritic cells in combination with activated $\mathrm{T}$ lymphocytes infiltrating primary cutaneous melanoma is a strong independent prognostic factor. Cancer Immunol. Immunother. 2007, 56, 1459-1469. [CrossRef] [PubMed]

266. Dyduch, G.; Tyrak, K.E.; Glajcar, A.; Szpor, J.; Ulatowska-Bialas, M.; Okon, K. Melanomas and Dysplastic Nevi Differ in Epidermal CD1c+ Dendritic Cell Count. Biomed. Res. Int. 2017, 2017, 6803756. [CrossRef]

267. Cubillos-Ruiz, J.R.; Silberman, P.C.; Rutkowski, M.R.; Chopra, S.; Perales-Puchalt, A.; Song, M.; Zhang, S.; Bettigole, S.E.; Gupta, D.; Holcomb, K.; et al. ER Stress Sensor XBP1 Controls Anti-tumor Immunity by Disrupting Dendritic Cell Homeostasis. Cell 2015, 161, 1527-1538. [CrossRef] [PubMed]

268. Ohm, J.E.; Shurin, M.R.; Esche, C.; Lotze, M.T.; Carbone, D.P.; Gabrilovich, D.I. Effect of vascular endothelial growth factor and FLT3 ligand on dendritic cell generation in vivo. J. Immunol. 1999, 163, 3260-3268. [PubMed]

269. Demoulin, S.; Herfs, M.; Delvenne, P.; Hubert, P. Tumor microenvironment converts plasmacytoid dendritic cells into immunosuppressive/tolerogenic cells: Insight into the molecular mechanisms. J. Leukoc. Biol. 2013, 93, 343-352. [CrossRef] 